\title{
POPULARITY IN HOUSE PREFERENCE - A RESEARCH ON USER SATISFACTION: BURSA BALAT SAMPLE ${ }^{1}$
}

\section{KONUT TERCIHINDE POPÜLARITE - KULLANICI MEMNUNIYETİ ÜZERINE BİR ARAŞTIRMA: BURSA BALAT ÖRNEĞİ}

\author{
Miray GÜR ${ }^{1}$, Filiz ŞENKAL SEZER ${ }^{2}$ \\ ${ }^{1-2}$ Uludag University, Faculty of Architecture, Bursa / Turkey

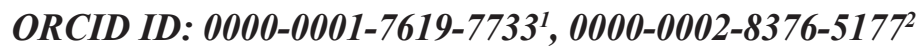

\begin{abstract}
Öz: Amaç: Bu araștırmanın amacı, kapalı yerleşmelerin sunduğu yaşam biçiminin etkisiyle popülerleșen yerleşimlerde, bu yaşam biçimini tercih eden kullanıcıların tercihlerini belirleyen kriterlerin önem siralaması ve memnuniyet düzeylerinin karşıllaştırılması aracılı̆ıılla artan popülaritenin nedenselliğinin fiziksel ve sosyo-ekonomik boyutlarılla açıklanmasıdır. Calışma literatür taraması, kullanıcı memnuniyeti anketinin değerlendirilmesi ve araş̦trma bulgularının tartışılmasından oluşmaktadır. Yöntem Kapalı yerleşmelerin sunduğu sosyal kimlik ve yaşam tarzının etkisiyle son yıllarda Bursa'da oldukça popülerleșen, talep ve arzın yoğun olduğu Balat semtinde kullanıcıların tercihini ve memnuniyetini etkileyen faktörlerin belirlenmesi amacıyla, altı kapalı yerleşmenin kullanııılarıyla anket çalışması yürütülmüștür. Değerlendirme kullanıcı niteliklerinin yanısıra, konut nitelikleri, konut sitesine ve semte ait nitelikler bağlamında gerçekleştirilmektedir. Memnuniyet düzeylerine ve önem derecesine iliskin elde edilen verilerin karşılaştırılması amacıyla, kullanıcı cevaplarına göre konut siteleri 5'li Likert ölçeğine göre puanlandırılmıştır. Bulgular: Konut tercihinde öncelik deprem güvenliğinin olması, konut sitelerinin tercih edilmesindeki öncelik ise sitenin güvenli olması, kullanıcıların kendilerini güvende hissetmesidir Anket verileri bu faktörlerden memnuniyet düzeyinin de yüksek olduğunu göstermiștir. Tercih sırasında önemli olmamasına rağmen, kullanıcıların sosyal statü açısından benzer ailelerle birlikte yaşamaktan çok memnun olduğu görülmüştür. Balat'ın tercih edilmesinde en önemli faktör olan ulaşım ağına erişebilirlik ve ağın kullanışlılığına ilişkin memnuniyet düzeyinin çok düşük olduğu görülmektedir. Bunun yanısıra trafik tüm semt için rahatsızlık kaynağıdır. Sosyal cevreye ilişkin olarak semtin tercih edilmesi aşamasında orta derecedeki önemine rağmen, semtin elit olmasından ve yaşanan sitenin Balat'ta yer almasından memnuniyetin çok yüksek olduğu görülmektedir. Sonuç: Zaman içerisinde tercihleri etkileyen kriterlerden memnuniyet düşük olabilmekte, ancak tercih sırasında öncelik taşımayan birtakım faktörler yaşantı sırasında kullanıcıları cok memnun edebilmektedir. Araştırma sonuçları gündelik yaşantıyı olumsuz etkileyerek memnuniyetsizliği doğuran sorunların geri planda kaldığını, belirli bir sosyal statü grubuna ait bireyler olmak ve bu niteliklerdeki diğer bireylerle birlikte ayrıcalıklı bir yaşam biçimi sürdürmek ile ilişkili olarak Balat'ın kullanıcı tercihlerini etkilediğini ve popüler bir semt haline geldiğini ortaya koymaktadır.

Anahtar Kelimeler: Konut, Kapalı Yerleșim, Popülarite, Kullanıcı Memnuniyeti
\end{abstract}

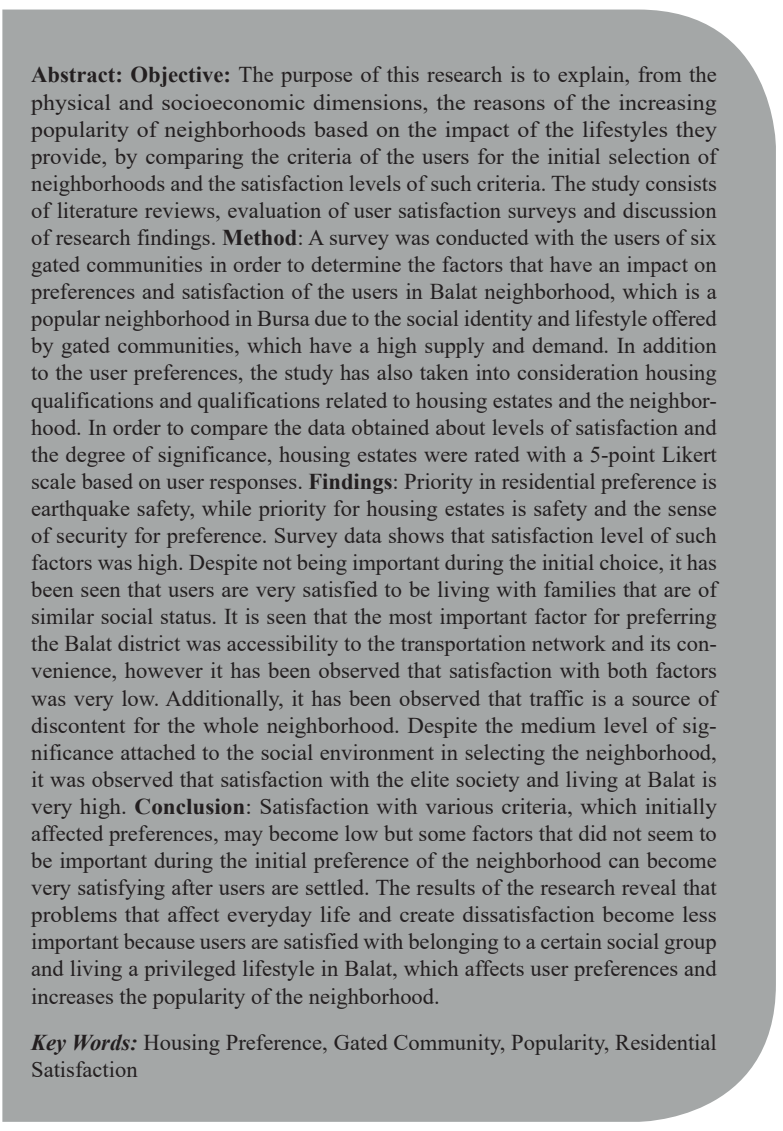

Doi: $10.17365 / T M D .2018 .2 .3$

(1) Responsible Author: Miray GÜR, Uludag University, Faculty of Architecture, Bursa / Turkey, miraygur@gmail. com, Gelis Tarihi: Received: 14.02.2018 - Kabul Tarihi: Accepted: 26.08.2018 Makalenin Türü: Typeofarticle (Araştırma ve Uygulama / Research and Application) Çıkar Çatışmast - Conflict of Interest: Yok / None "Etik Kurul Raporu Yok - No Ethics Committee Report 


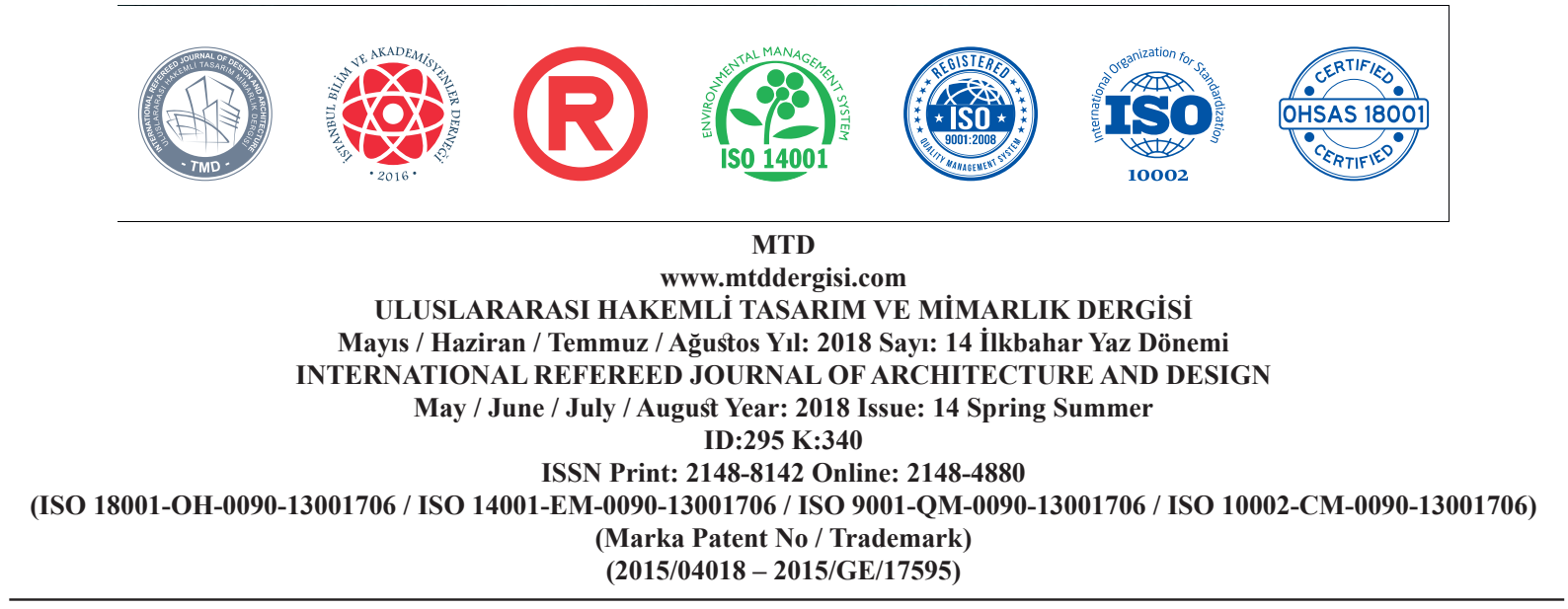

\section{INTRODUCTION}

Socio-psychological factors are quite effective in the housing selection of residents alongside the factors associated with physical and social needs. It is known that moving to a new house (especially when a large amount of resources is invested) and social status in relation to economic welfare bring satisfaction and notable well-being to residents (Clapham et al., 2017: 269, Tran and Van Vu 2018: 864, Frijters et al., 2011: 197-205, Wolbring 2017: 1371).

Gated communities which are symbols of social status have spread throughout the world, beginning in America in the 1970s when globalization gained momentum. Such housing estates, which are surrounded by walls, protected by special security measures and electronic systems have also started to be constructed in Turkey in 1980s. The reasons that motivate people to choose to live on such housing estates are the search for a sense of security along with changes in social and everyday life.

Roitman (2005: 304-305) considers the reasons for the prevalence of gated communities in two groups: structural and subjective. The first group consists of trends such as increased insecurity, fear of crime, increasing social inequality, and polarization. The subjective reasons in the second group can be summa- rized as families that want better life styles, social homogeneity, status and privilege. This is closely related to income levels and the need for gathering in a particular place, and has been found to be frequent in communities with high income disparities. The lifestyle of gated communities creates satisfaction for the inhabitants, who also feel satisfied with the homogeneity in their lifestyle, management of the community and social presentation (Blakely and Synder, 1997: 71).

Factors that users value in their choice of a gated community as a housing site and factors that satisfy them can be different. Factors such as environmental quality, aesthetic appearance, quality of social facilities and maintenance services, which are related to the residential area; location of the residential area within the city, proximity to workplace, which are related to the quarter; community feeling, social connections with the neighbors, which are related to the social environment come to the forefront for user satisfaction even that they are not important initially when preferring such housing estates (Carvalho et al., 1997: 757-761). Under the light of all these data, the above-mentioned needs which are effective in housing selection turn into a lifestyle over time and gain importance in the choice of residences.

The starting point of the study is that whether these factors which are effective in preference 


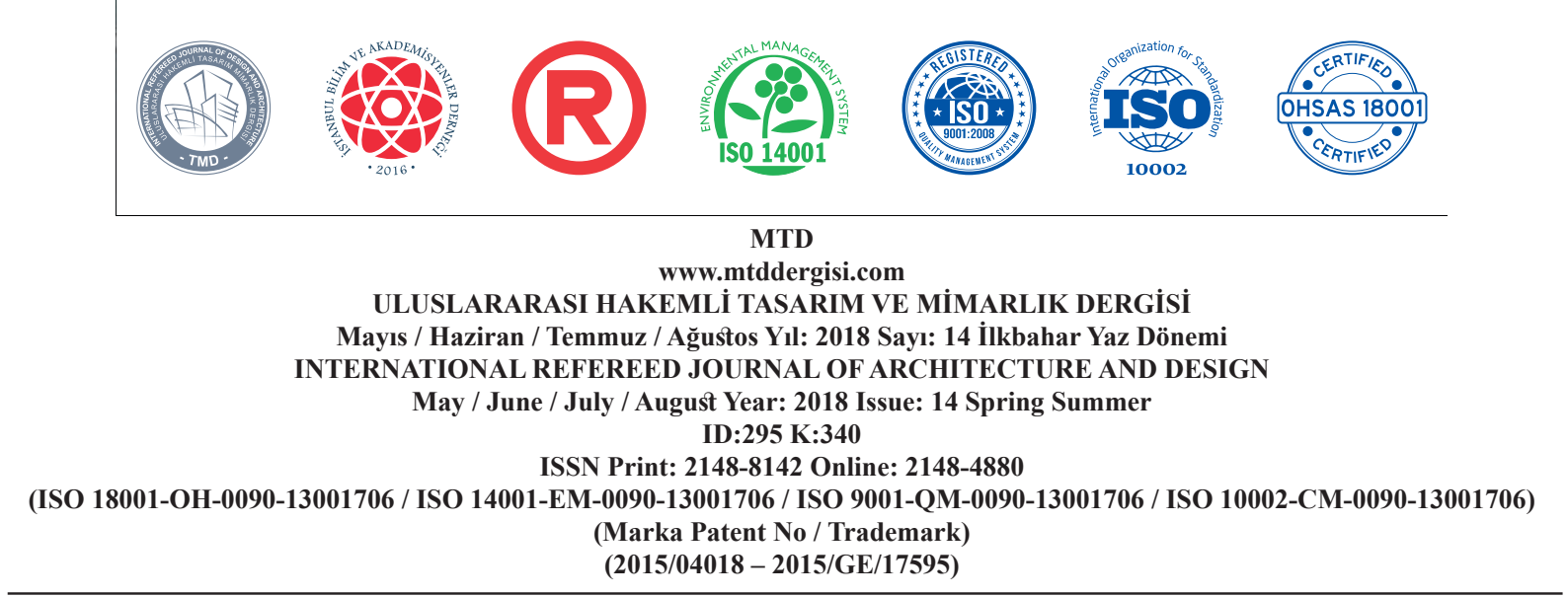

of the houses that are located in gated communities have the same importance after usage or not and to determine the satisfaction levels concerning these factors. As well as lifestyle, social environment and safety factors in housing preference, the concept of "popularity" comes to the forefront in gated communities along with purchasing power. Residents prefer these housing estates as a representation of lifestyle and purchase which are considered to be an indicator of prestige. In accordance with the objective concerning to investigate the factors that are effective in preference of gated communities and satisfaction, a case study is conducted in Balat Bursa that has developed and has been developing rapidly where gated communities appealing to high income groups are prevalent and housing sales prices are higher in comparison with other regions in the city.

\section{AIM}

The objective of this research paper is to examine the factors affecting preference of users and their satisfaction levels of the mentioned factors / preferences related to gated communities, which have increased in popularity in recent years due to the influence of the lifestyle provided by them and have a large supply and demand. In this context Balat neighborhood in Nilüfer district in Turkey's fourth largest city Bursa was chosen as the study area. The study evaluates what factors are significant for users, who have selected this area and preferred this kind of a lifestyle. The evaluation takes into consideration user features, housing qualities and qualities related to the housing estates and the neighborhood. Studies on the preferences and satisfaction that influence housing demands, including the gated communities, show that neighborhoods are evaluated with factors of housing qualities, quality of the facilities provided by the housing area/site, and social and physical qualities (Carvalho et al., 1997: 749, Chapman, Lombard, 2006: 787-788, Sirgy and Cornwell 2005, Jun, 2013: 399-400). Therefore, in addition to the qualities related to gated communities, qualities that made Balat neighborhood popular should also be taken into consideration.

\section{CONTENT}

In order to determine the factors affecting the preference and satisfaction of the users in Balat, which is a very popular district in Bursa due to social identity and lifestyle it provides via the physical opportunities provided by gated communities, a survey was conducted with the inhabitants of six gated communities, namely Heybeli Konakları, Turkuaz Plus, Bakgor City 1, Egemen Evler, Greenpark, Dikencik Country 2, which were selected based on criteria related to residence qualities, location in the neighborhood and 


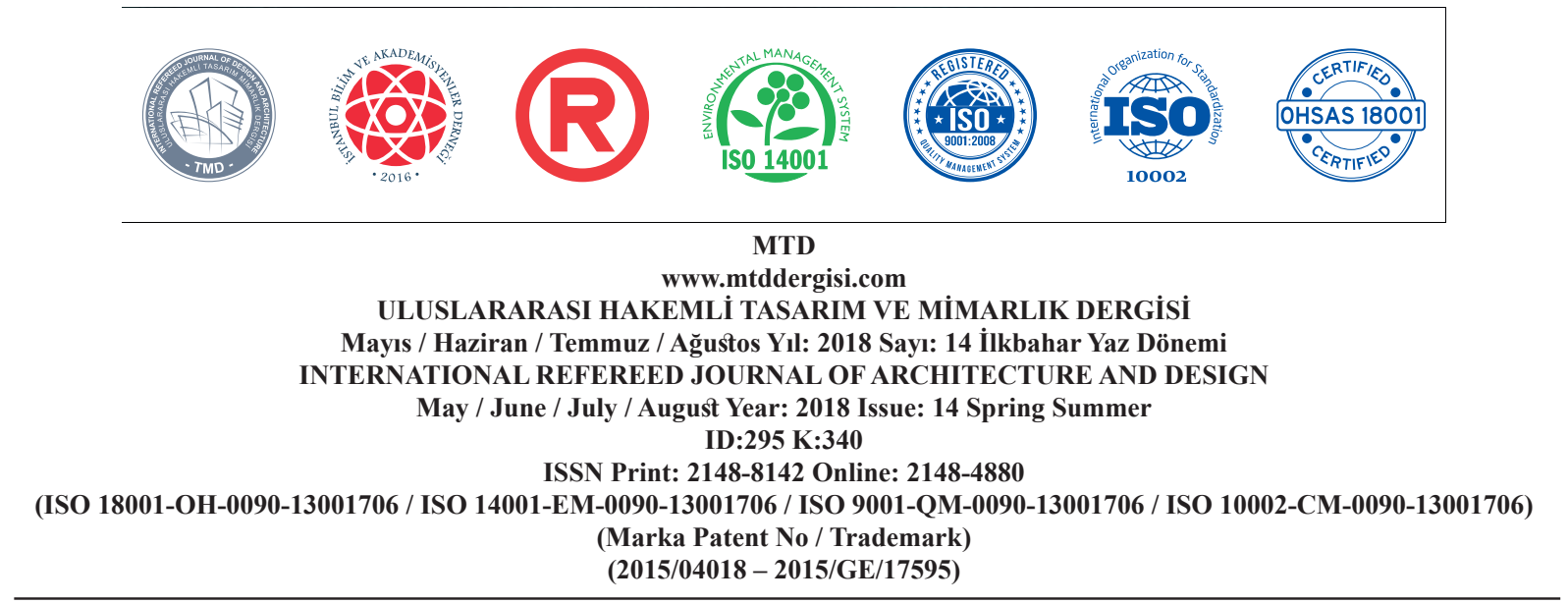

the facilities provided by each gated community.

Determination of user satisfaction during building usage is a method to increase building efficiency and to influence future building designs. In this context, the benefits of the Post Occupancy Evaluation (POE) system can be summarized as, identifying building problems and their solutions in a short period of time, improving feedback on building performance and space usage, creating significant cost savings throughout the building process and building life cycle, providing long-term improvements in building performance, and creating information sources to improve databases, standards and criteria. By examining user preferences and the level of satisfaction with such preferences in gated communities through Post Occupancy Evaluation, it is expected to receive answers related to building supply and to contribute to the literature by studying the reasons behind the popularity of the neighborhood with causal explanations related to the satisfaction levels of various reasons for preferring such residences.

\section{RESEARCH METHOD}

The survey was developed based on the Likert scale and questions which aim to identify the level of satisfaction. The scale used to measure satisfaction level is defined as absolutely agree, agree, neither agree nor dis- agree, disagree, strongly disagree, including can't choose. In a similar way, the importance levels are defined as 'absolutely important', 'important', 'neither important nor not important', 'not important', 'strongly not important', and 'can't choose'. From this point of view, a fieldwork was conducted to determine the factors that users put emphasis on and compare their satisfaction about these factors under three headings: A) houses, B) housing areas (gated communities) and $\mathrm{C}$ ) neighborhood (Balat-case study). The method that is used to compare the data obtained about the satisfaction and importance levels through the questionnaire is scoring gated communities based on the answers given by the users.

The questionnaire has 21 questions regarding the key themes, which are user's perception of physical features of the houses, such as architectural qualities, construction quality, equipment, earthquake safety within features of the housing areas; social, recreational facilities, public open spaces, sports facilities, parking area, safety measures, social status, social safety within features of the housing area; accessibility to shopping facilities, public transportation, the location in the city, social environment, social facilities, traffic density, the perception about living there, eliteness within features of the neighborhood. To ensure consistency, $33 \%$ of the users living in each area were interviewed. In the case study 


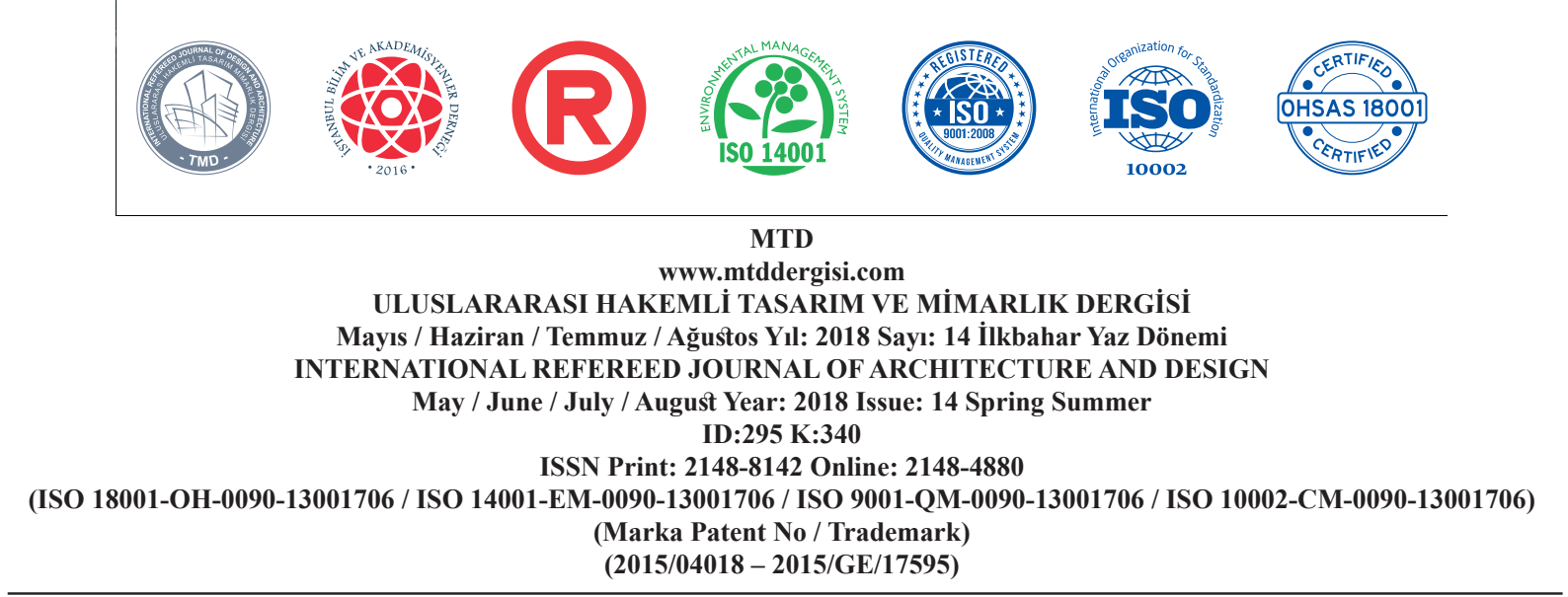

performed in December 2017, a proportional distribution approach was selected to distribute the sampling volume to layers.

\section{RESEARCH RESTRICTIONS}

The restriction of this research can be stated as conducting the surveys and gathering data within case study in the determined gated communities in Balat related to the scope of the study. Problems had arisen for researchers in data gathering process for entering the estates and interviewing the residents because of the security in gated communities. These problems are hurdled by meetings between all of the site managements and researchers. The site managers reviewed the survey questions, evaluated them with the perspective of wellbeing of the site residents and made effort to gloss over the negative opinions about the housing estates. In this context, the security and the attitude of the management made the survey process difficult devoted to examine the preferences and satisfaction of the residents. The sample group is reached through the existing personal relationships of the researchers with some of the residents. It is another restriction that the envisaged time calendar is exceeded in the process of the interviews that are made to get the answers of the questionnaires. The tough part of the study was to obtain the determined sample ratio and to conduct the survey in the gated communities that are one of the symbols of safety and prestige and the case study is conducted with personal connections and day-today visits to areas.

\section{RESEARCH PROBLEM}

The research problem is to examine user preferences and the satisfaction with such preferences in gated communities in the Balat neighborhood of Bursa, where supply and demand increased together with its popularity since 2010 . The research problem is to explain the reasons of the increasing popularity of the neighborhood from the physical and socioeconomic dimensions by comparing the criteria of the users for the initial preference of the neighborhood and the satisfaction levels of such criteria.

\section{RESEARCH BOTTOM PROBLEMS}

The bottom problems of the research can be stated as; a) to determine the physical and socioeconomic dimensions that come to the forefront in the preference of the region by the residents, b) to find out which factors concerning house, housing estate or neighborhood become prominent for user preferences, c) to determine the social and physical dimensions in all of these environmental scales that affect the preferences and satisfaction levels, d) to investigate the degree of matching between the factors that are effective in user preferences and satisfaction levels. 


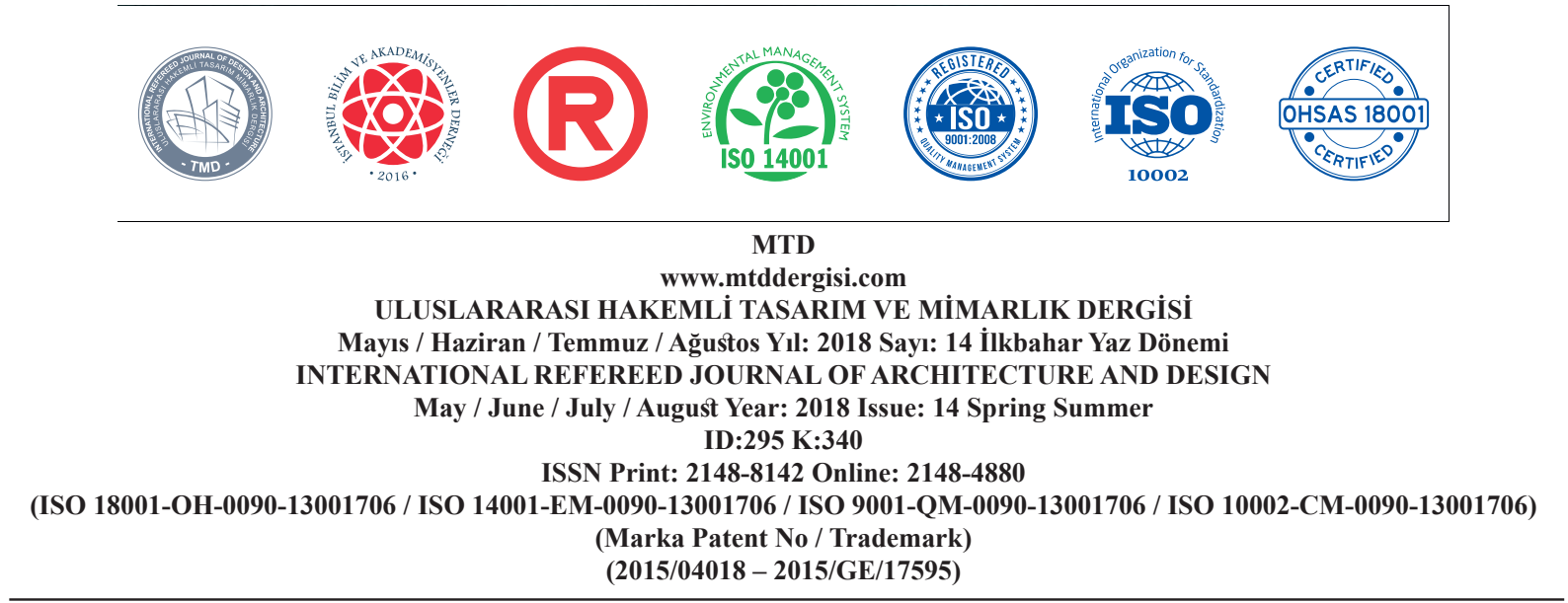

\section{RESEARCH HYPOTHESES}

When the primary reasons for users in preferring gated communities are evaluated from the residence perspective it can be seen that users give importance to well-equipped houses, architectural qualities meeting expectations of users, and earthquake safety. When the same is evaluated from the gated community perspective it can be seen that users prefer gated communities primarily for safe living, but over time the closed and privileged lifestyles provided by the gated communities also increase user satisfaction. Similar to the sense of security, it is expected that living together with families with similar socioeconomic status will become a quality that will increase satisfaction over time. In relation to the privileged life provided by housing sites, it is observed that because these gated communities are in Balat neighborhood and because Balat is a neighborhood that belongs to the elite society, the satisfaction of users, who demand a privileged lifestyle, increases together with the popularity of Balat neighborhood. However, together with the increase of housing supply and demand, it is predicted that the transportation network for users will not meet the demand and traffic density will become problematic and user satisfaction may be negatively affected. In addition, it is anticipated that the commercial sites, which are concentrated in one area, will increase the satisfaction of those who live close by because of the ability to easily meet daily needs, while those living at remote locations may be dissatisfied. However, given the popularity of Balat, it is expected that other criteria of the socioeconomic privilege might suppress other criteria.

\section{THEORETICAL FRAME}

In this study, under the title of the theoretical frame, the researches on the factors affecting the preferences and satisfaction levels of the residents were examined. In this context, all the studies examined have supported the determination of the factors considered in the case study. When the factors affecting housing preferences that guide the user groups are examined, based on different studies, it is observed that demographic characteristics, housing qualifications, possibilities provided by gated communities, social environment and qualities related to the neighborhood become important (Chapman, Lombard, 2006: 796, Sirgy and Cornwell 2005: 110-112, Ha and Weber 1991: 73-74, Lee et al., 2007, Teck-Hong 2012: 113-114, Jun, 2013: 401402). While physical features and quality are important in most of the studies related to factors that affect satisfaction with residences (Türkoğlu 1997: 63-65, Li and Song 2009: 1103-1105, Salleh 2008: 491), in some studies, perception of social and recreational possibilities and the perceptions related 


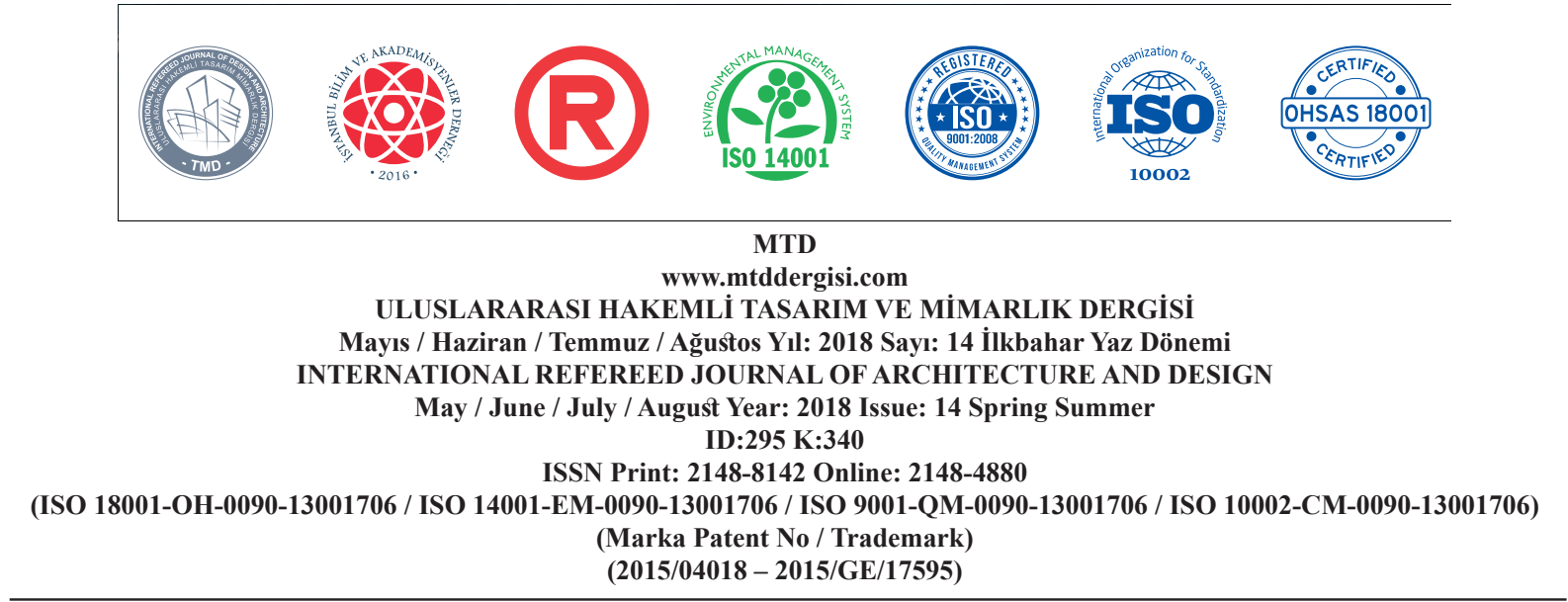

to the residential area come to the forefront (Berköz 2008, Türkoğlu 1997: 64-65, Salleh 2008), while in other studies accessibilitytransportation (Berköz et al., 2009: 171-172, Ibrahim 2017: 103-104, Li and Song 2009: 1104), security (Amerigo Aragones 1997: 5455 ), sense of belonging and loyalty (WilsonDoenges 2000: 606, Sam et al., 2012: 34-37, Qiao et al., 2018: 200-203), and residence prices (Lee et al., 2007: 21-23) gain importance. For physical aspect of residences, the layout and size and how much it is equipped are important features, and for the social environment the users living in the area are important factors affecting if the residence will be selected; and residences may not be preferred if services for the upkeep of the gated community is believed to be subpar (Lee et al., 2007:18).

Availability of public transportation options (Jun, 2013: 403, Berköz et al., 2009), quality of the environment and affordability come to the forefront as some of the reasons affecting the preference of a residence, and the social environment can also become important for future preferences (Ibrahim, 2017: 103-104). It is a fact that housing prices increase if they offer facilities and services demanded by the users, which triggers a social and spatial divide (Jun, 2013: 401-402).

The qualifications sought in gated communities can be customized depending on the demand. In a survey conducted in the United States, the importance placed on recreational areas in gated communities was more important (Chapman, Lombard, 2006: 793), in a study conducted in Brazil, qualities such as location, security and social facilities were important (Carvalho et al., 1997: 757-762), while in Turkey security and a privileged life, and also earthquake safety were important factors affecting popularity of gated communities (Özkan Töre and Kozaman Som, 2009: 126-128). The concept of residence satisfaction related to raising children in a safe area is associated with multifamily satisfaction and different generations (Lee et al., 2007: 25-28, Chapman, Lombard, 2006: 791-795). Compared to housing estates with no security, gated communities seem to have a higher level of satisfaction, while in some areas it is observed that satisfaction is created by neighborhood experience (Teck-Hong, 2012: 112114, Chapman, Lombard, 2006: 785-790). Preference of a building type is related both to the purchasing power and to the need for a sense of security.

The concept of "popularity" come into prominence in relation to safety and purchasing power, and regardless of high prices, users prefer housing sites, which are considered to be an indicator of prestige. Factors that make gated communities popular were grouped into urban, social, and economic factors; and 


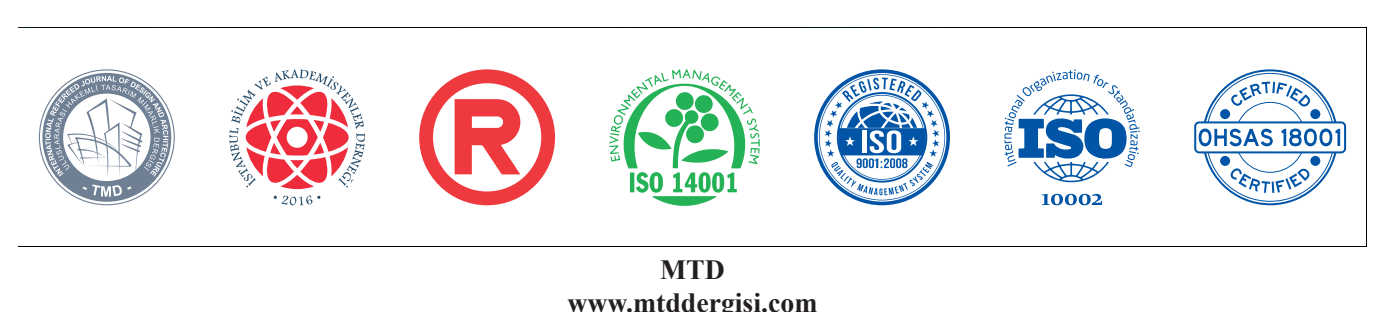

www.mtddergisi.com

ULUSLARARASI HAKEMLİ TASARIM VE MIMARLIK DERGISİ

Mayıs / Haziran / Temmuz / Ağustos Yıl: 2018 Sayı: 14 İlkbahar Yaz Dönemi

INTERNATIONAL REFEREED JOURNAL OF ARCHITECTURE AND DESIGN

May / June / July / August Year: 2018 Issue: 14 Spring Summer

ID:295 K:340

ISSN Print: 2148-8142 Online: 2148-4880

(ISO 18001-OH-0090-13001706 / ISO 14001-EM-0090-13001706 / ISO 9001-QM-0090-13001706 / ISO 10002-CM-0090-13001706)

(Marka Patent No / Trademark)

$(2015 / 04018-2015 / G E / 17595)$

comfort and technological factors by Yuksel and Akbulut (2009) and the preference and demand derives from provision of a safe space, parking areas, response to the society of the spectacle's search for an identity and consumption needs, and provision of services and technology.

\section{CASE STUDY}

Bursa with a population of 2.5 million is the $4^{\text {th }}$ most populated metropolitan city in Turkey. In Bursa before the 1980s, gated communities were popular for the upper and middle income groups for reasons such as large green areas, being close to the city center, no parking problems, social facilities located in the residential area, and security (Dostoglu, 2000: 66-67). Ergin Evler project, which was started to be built in 2000 in phases, was the first example of the gated communi- ties in Balat; because it received popularity from highly educated, high and mid income groups, who were employed in the organized industrial zone nearby, the appeal of Balat has progressively increased since 2005. Finally, in a survey conducted on the preferences of individuals for housing areas in 2017, it was seen that the most preferred region in Bursa metropolitan area is in Nilufer district with a rate of $32 \%$, where the neighborhood of $\mathrm{Ba}$ lat is located (Mutlu, Varol 2017: 96). Today, despite the slum areas that are in the immediate vicinity of Balat, the neighborhood has become the most popular residential district where demand and supply are high and has become the most preferred neighborhood for the upper income groups. In Figure 1, case study locations are marked on the aerial photograph (URL - 2).

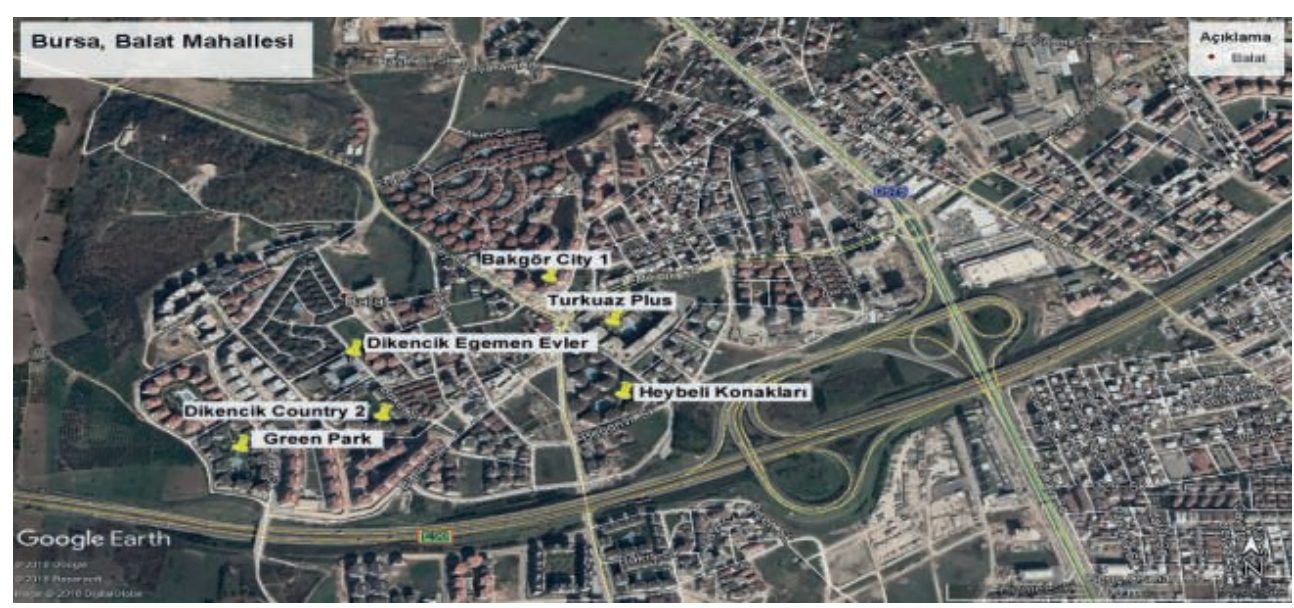

Figure 1. Location of the Case Buildings 


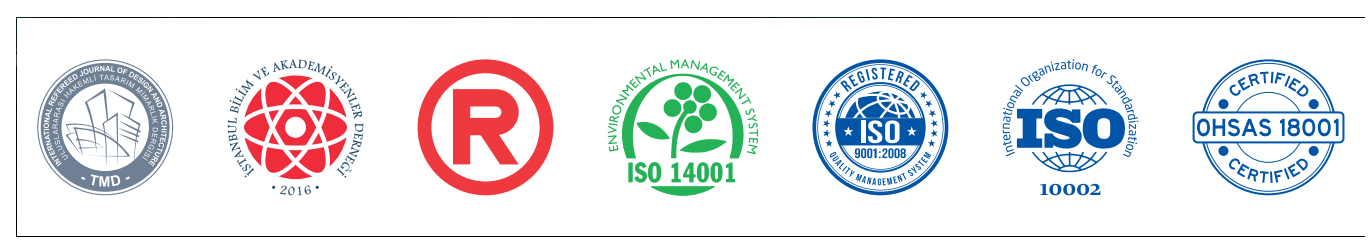

MTD

www.mtddergisi.com

ULUSLARARASI HAKEMLİ TASARIM VE MIMMARLIK DERGİİ

Mayıs / Haziran / Temmuz / Ăgustos Yıl: 2018 Sayı: 14 İlkbahar Yaz Dönemi

INTERNATIONAL REFEREED JOURNAL OF ARCHITECTURE AND DESIGN

May / June / July / August Year: 2018 Issue: 14 Spring Summer ID:295 K:340

ISSN Print: 2148-8142 Online: 2148-4880

(ISO 18001-OH-0090-13001706 / ISO 14001-EM-0090-13001706 / ISO 9001-QM-0090-13001706 / ISO 10002-CM-0090-13001706)

(Marka Patent No / Trademark)

$(2015 / 04018-2015 / G E / 17595)$

Sample A (Heybeli Konakları): Consists of 13 blocks located on an area of $34.000 \mathrm{~m}^{2}$ and has a total of 240 apartments. The apartments in the residential area, which has 24 hours' security, consist of $2+1,3+1,4+1$ and $5+1$ apartments. All of the 5+1 apartments are duplex and are located either at the loft or the garden floor; each building block has 1 loft duplex and 3+1 apartments. There are open and closed car parks, walk and bicycle paths, playgrounds for children, 2 outdoor swimming pools, tennis, basketball and mini football fields, cafeteria and fitness room, and a $25.000 \mathrm{~m}^{2}$ green area (Figure 2-3).
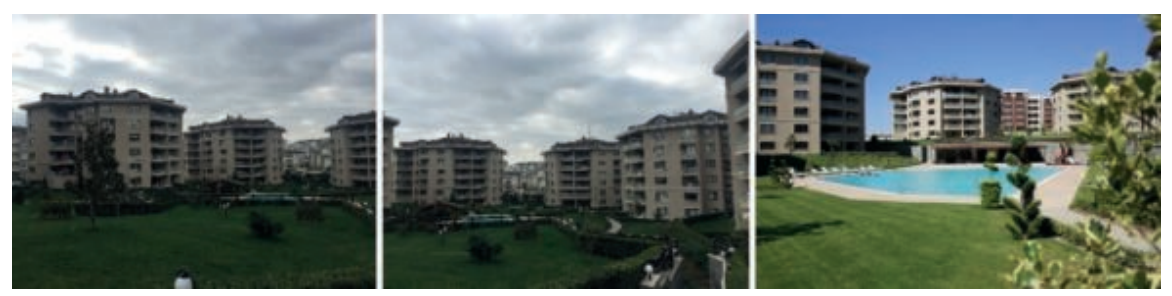

Figure 2. Photographs From the Outside of Sample A
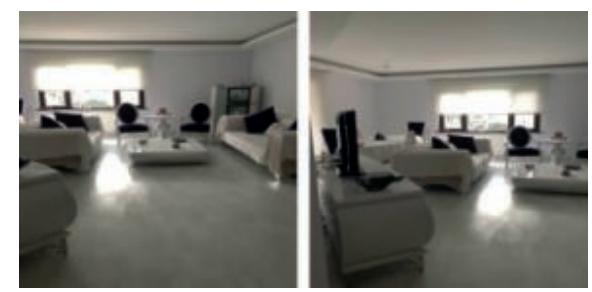

Figure 3. Photographs From the Inside of Sample A

Sample B (Turkuaz Plus): This apartment consists of 9 blocks located on $30.000 \mathrm{~m}^{2}$ lands and has 195 apartments with $3+1,4+1$ and $5+1$ options. There are $4+1$ single story houses, garden, mezzanine or loft duplex options, and 5+1 loft duplex apartments. Alongside a green area of approximately $17.000 \mathrm{~m}^{2}$ and facilities such as a walking track, swimming pool, fitness center, basketball court, children's playground, sauna, social facilities, there is a bazaar with commercial functions and 34 shops, which serves the Balat neighborhood (Figure 4-5). 


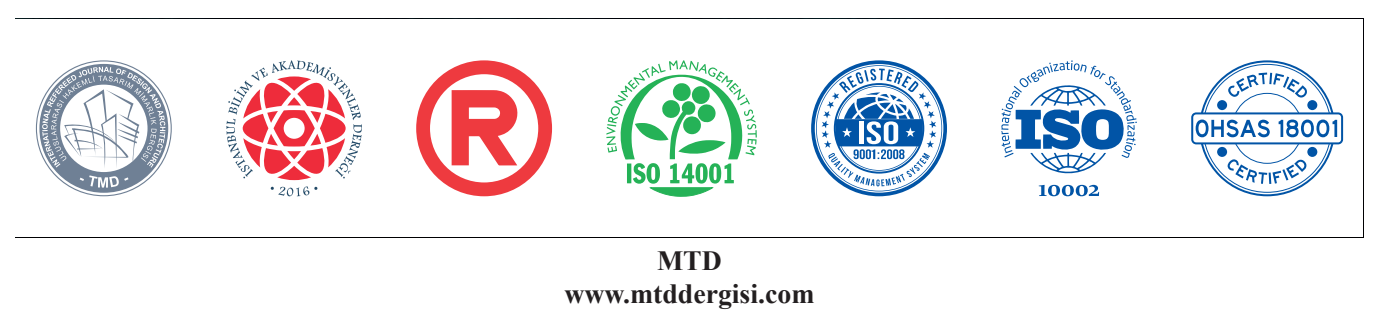

www.mtddergisi.com

ULUSLARARASI HAKEMLİ TASARIM VE MIMARLIK DERGISİ

Mayıs / Haziran / Temmuz / Ağustos Yıl: 2018 Sayı: 14 İlkbahar Yaz Dönemi

INTERNATIONAL REFEREED JOURNAL OF ARCHITECTURE AND DESIGN

May / June / July / August Year: 2018 Issue: 14 Spring Summer ID:295 K:340

ISSN Print: 2148-8142 Online: 2148-4880

(ISO 18001-OH-0090-13001706 / ISO 14001-EM-0090-13001706 / ISO 9001-QM-0090-13001706 / ISO 10002-CM-0090-13001706)

(Marka Patent No / Trademark)

$(2015 / 04018-2015 / G E / 17595)$

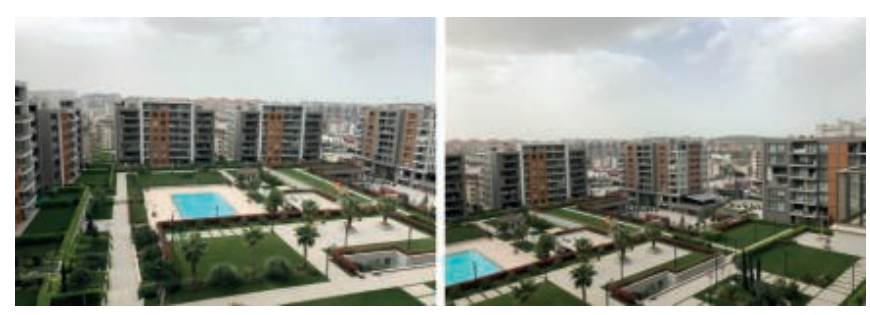

Figure 4. Photographs From the Outside of Sample B
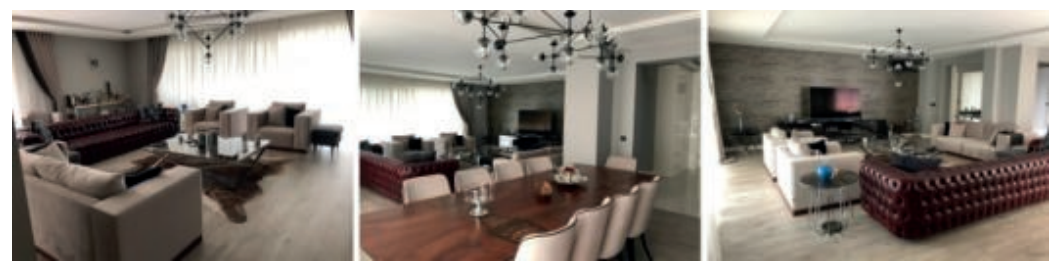

Figure 5. Photographs From the Inside of Sample B

Sample C (Bakgör City 1): There are 10 indoor swimming pool for men and women building blocks with a total of 271 apartments, and an indoor sports hall. In addition, there which are all are $4+1$. It has a recreational are 61 stores with different commercial funcarea of $10.000 \mathrm{~m}^{2}$, a closed car park for 500 tions serving the Balat neighborhood on the cars, 24-hour security, children's playground, ground level of the site (Figure 6-7).
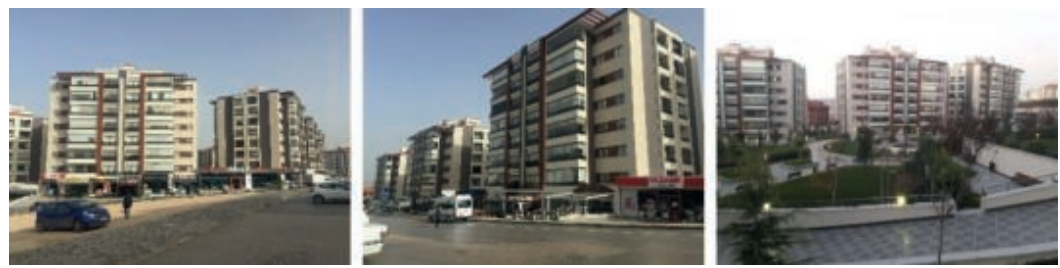

Figure 6. Photographs From the Outside of Sample C
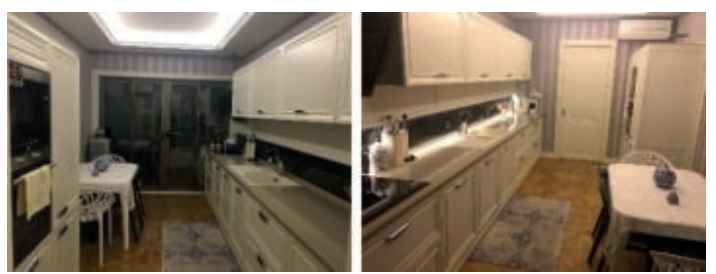

Figure 7. Photographs From the Inside of Sample C 


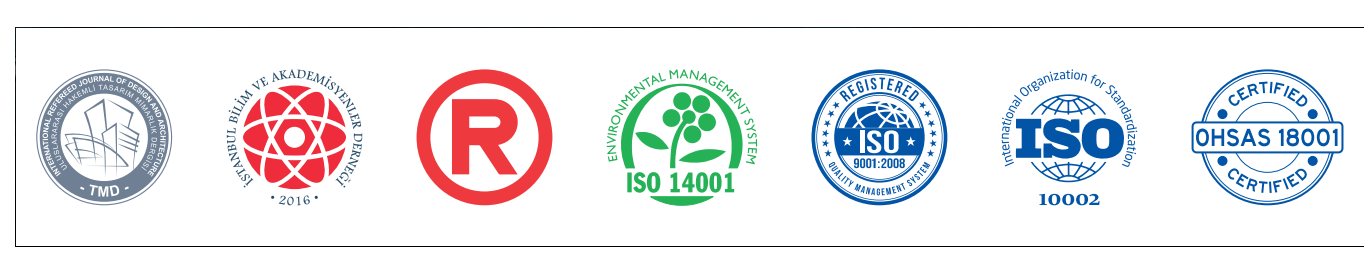

MTD

www.mtddergisi.com

ULUSLARARASI HAKEMLİ TASARIM VE MIMARLIK DERGISİ

Mayıs / Haziran / Temmuz / Ağustos Yıl: 2018 Sayı: 14 İlkbahar Yaz Dönemi

INTERNATIONAL REFEREED JOURNAL OF ARCHITECTURE AND DESIGN

May / June / July / August Year: 2018 Issue: 14 Spring Summer ID:295 K:340

ISSN Print: 2148-8142 Online: 2148-4880

(ISO 18001-OH-0090-13001706 / ISO 14001-EM-0090-13001706 / ISO 9001-QM-0090-13001706 / ISO 10002-CM-0090-13001706)

(Marka Patent No / Trademark)

$(2015 / 04018-2015 / G E / 17595)$

Sample D (Egemen Evler): There are 48 apartments with a size ranging from 298 to $304 \mathrm{~m}^{2}$ and all apartments are 4+1 (Figure 8-9). There is indoor parking for 2 cars per apartment, indoor and outdoor children's playground, outdoor swimming pool, outdoor children's pool, and decorative pools, a basketball court, fitness center, cafeteria, sauna for men and women, 24 hours' security, 4500 $\mathrm{m}^{2}$ green area.
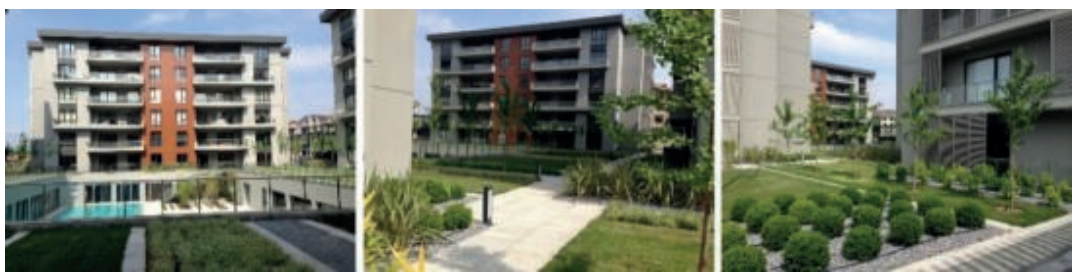

Figure 8. Photographs From the Outside of Sample D
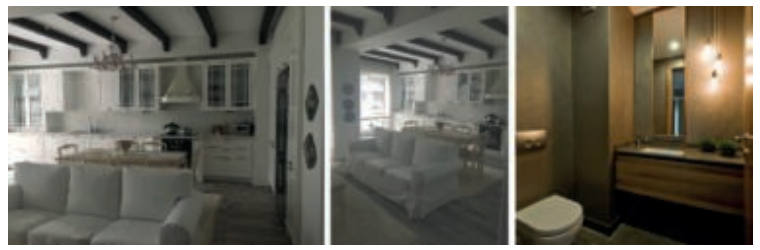

Figure 9. Photographs From the Inside of Sample D

Sample E (Green Park Dikencik Evleri):

There are 122 apartments in 12 blocks on a $25.000 \mathrm{~m}^{2}$ area; apartments are $3+1$ and $4+1$. $3+1$ apartments are 211-215 $\mathrm{m}^{2}, 4+1$ apartments are $264-320 \mathrm{~m}^{2}$ in size. There are green spaces, hiking trails, children playground, outdoor swimming pool, tennis courts, a cafeteria and a market in the gated community, which has 24 hours' security (Figure 10-11).

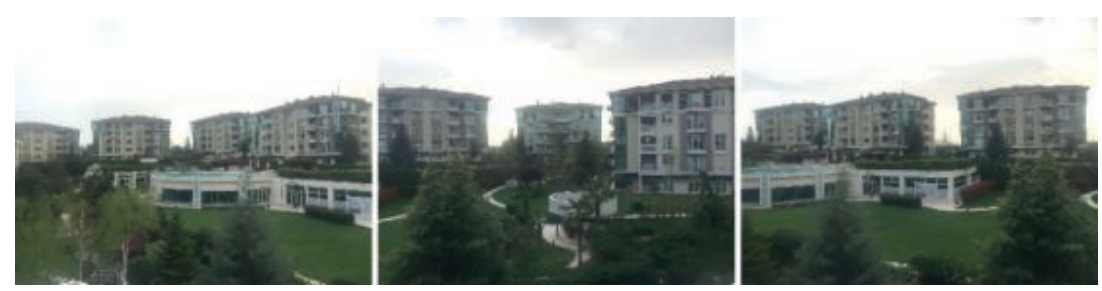

Figure 10. Photographs from the Outside of Sample E 


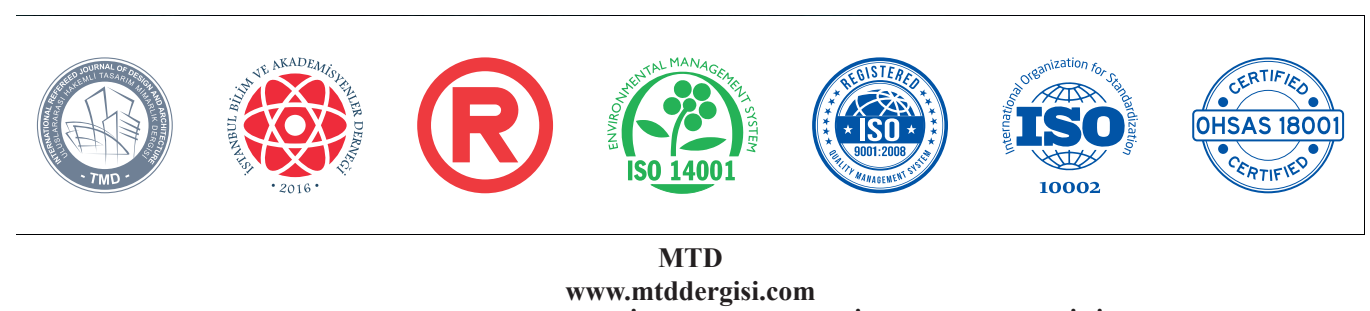

www.mtddergisi.com

ULUSLARARASI HAKEMLI TASARIM VE MIMARLIK DERGISİ

Mayıs / Haziran / Temmuz / Ağustos Yıl: 2018 Sayı: 14 İlkbahar Yaz Dönemi

INTERNATIONAL REFEREED JOURNAL OF ARCHITECTURE AND DESIGN

May / June / July / August Year: 2018 Issue: 14 Spring Summer ID:295 K:340

ISSN Print: 2148-8142 Online: 2148-4880

(ISO 18001-OH-0090-13001706 / ISO 14001-EM-0090-13001706 / ISO 9001-QM-0090-13001706 / ISO 10002-CM-0090-13001706)

(Marka Patent No / Trademark)

$(2015 / 04018-2015 / G E / 17595)$
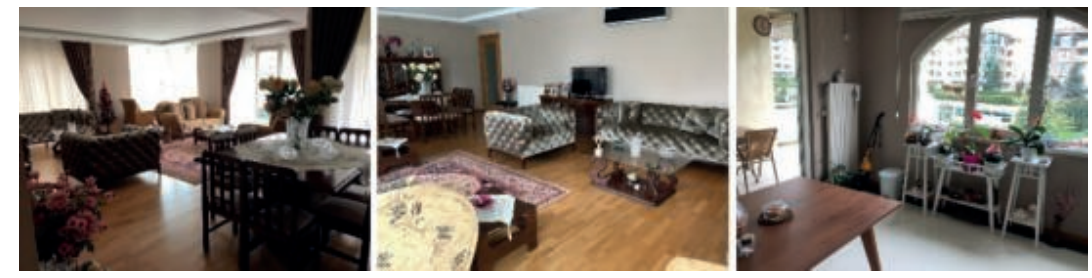

Figure 11. Photographs From the Inside of Sample E

Sample F (Dikencik Country 2): Situated on land of $20.870 \mathrm{~m}^{2}$, there are $884+1$ and $5+1$ apartments in 11 blocs. 4+1 apartments are $232 \mathrm{~m}^{2}$ and 5+1 duplex apartments are 322 $\mathrm{m}^{2}$ in size. There is a green and recreational area with a total area of $10.000 \mathrm{~m}^{2}$ with 24 hour security, closed car park for 2 cars for each apartment, children's playground, outdoor swimming pool, tennis, basketball and mini football fields (Figure 12-13).

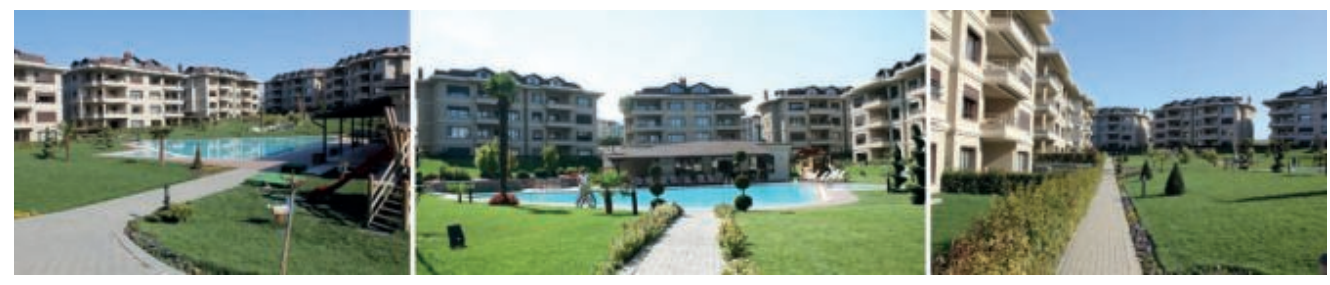

Figure 12. Photographs From the Outside of Sample F

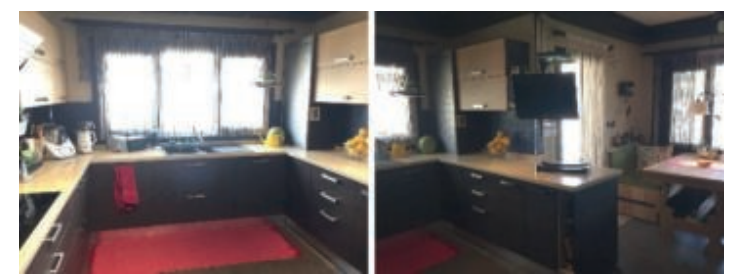

Figure 13. Photographs From the Inside of Sample F

\section{RESULTS}

The method that is used to compare the data obtained about the satisfaction and significance levels through the questionnaire is to score the gated communities based on the answers given by the users. In this context to understand the importance given to and the satisfaction with each of the factors, levels of importance and satisfaction were scored with +2 for absolutely important/agree, +1 for important/agree, 0 for neither agree nor disagree / neither important nor important and can't choose, -1 for disagree/not important, -2 for strongly not important/disagree. As a result 


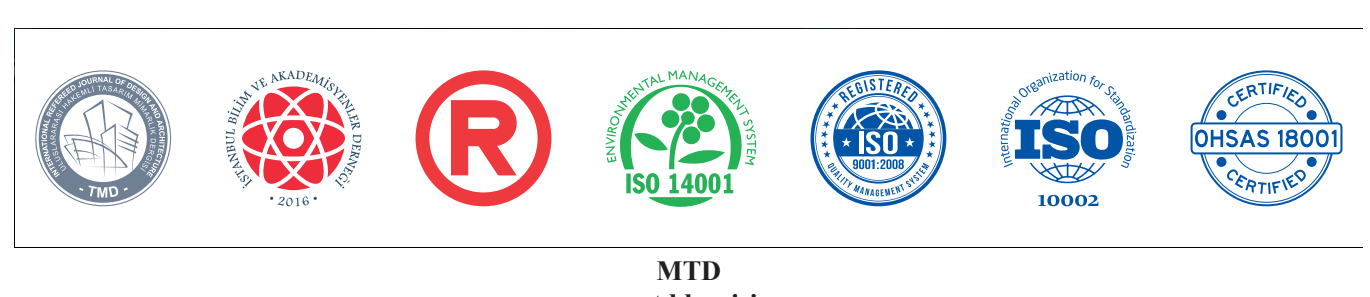

www.mtddergisi.com

ULUSLARARASI HAKEMLİ TASARIM VE MIMARLIK DERGİII

Mayıs / Haziran / Temmuz / Ăgustos Yıl: 2018 Sayı: 14 İlkbahar Yaz Dönemi

INTERNATIONAL REFEREED JOURNAL OF ARCHITECTURE AND DESIGN

May / June / July / August Year: 2018 Issue: 14 Spring Summer ID:295 K:340

ISSN Print: 2148-8142 Online: $2148-4880$

(ISO 18001-OH-0090-13001706 / ISO 14001-EM-0090-13001706 / ISO 9001-QM-0090-13001706 / ISO 10002-CM-0090-13001706)

(Marka Patent No / Trademark)

$(2015 / 04018-2015 / G E / 17595)$

of the assessment, user satisfaction regarding the factors considered more important was evaluated, and even if not at the top in the order of importance data about the physical and social facilities playing a strong role in increasing the level of satisfaction of the user were gathered. In the first section, four questions were asked, mainly consisting of the respondent's socio-demographic information. Demographic findings are shown separately for each of the housing estates (Table 1).

Table 1. Demographic Characteristics

\begin{tabular}{lcccccc} 
& \multicolumn{6}{c}{ Housing estates (Percentage) } \\
\cline { 2 - 7 } Gender: & Sample A & Sample B & Sample C & D & Sample E & Sample F \\
\hline Female & 69 & 51 & 43 & 84 & 44 & 42 \\
Male & 31 & 49 & 57 & 16 & 56 & 58 \\
\hline Age: & 2 & 0 & 3 & 0 & 4 & 0 \\
\hline Under 18 years old & 4 & 4 & 17 & 0 & 6 & 0 \\
18-25 years old & 24 & 24 & 20 & 37 & 23 & 19 \\
26-35 years old & 25 & 21 & 43 & 48 & 22 & 48 \\
36-45 years old & 26 & 33 & 8 & 10 & 31 & 19 \\
46-55 years old & 13 & 12 & 9 & 5 & 14 & 14 \\
56-65 years old & 6 & 6 & 0 & 0 & 0 & 0 \\
66 years or older & & & & & & \\
\hline Educational status: & & & & & & \\
\hline Secondary school & 13 & 2 & 12 & 1 & 2 & 0 \\
graduate & 32 & 15 & 35 & 55 & 30 & 39 \\
High school graduate & 49 & 74 & 46 & 39 & 50 & 57 \\
Bachelor's degree & 6 & 9 & 7 & 5 & 18 & 4 \\
Postgraduate & & & & & & \\
\hline Occupation: & 56 & 47 & 48 & 38 & 42 & 48 \\
\hline Employed & 15 & 30 & 9 & 10 & 25 & 23 \\
Retired & 5 & 2 & 14 & 0 & 4 & 0 \\
Student & & 21 & 29 & 52 & 29 & 29 \\
Housewife & & & & & & \\
\hline
\end{tabular}




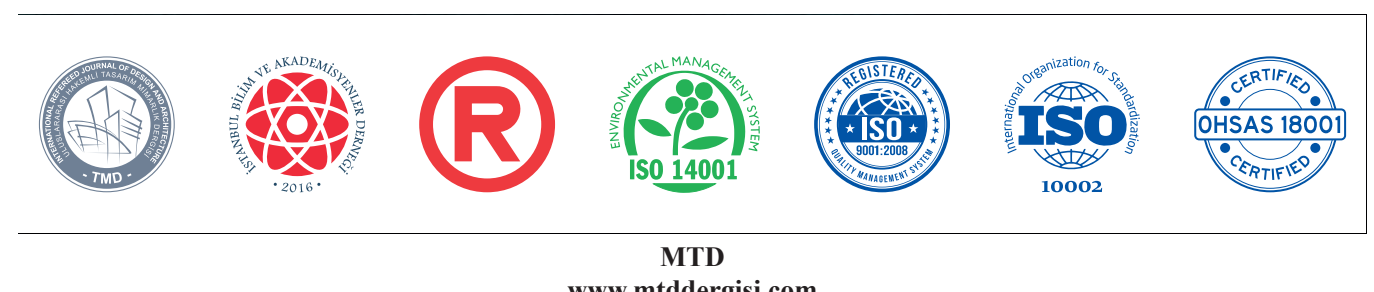

www.mtddergisi.com

ULUSLARARASI HAKEMLİ TASARIM VE MIMARLIK DERGISII

Mayıs / Haziran / Temmuz / Ağustos Yıl: 2018 Sayı: 14 İlkbahar Yaz Dönemi

INTERNATIONAL REFEREED JOURNAL OF ARCHITECTURE AND DESIGN

May / June / July / August Year: 2018 Issue: 14 Spring Summer

ID:295 K:340

ISSN Print: 2148-8142 Online: 2148-4880

(ISO 18001-OH-0090-13001706 / ISO 14001-EM-0090-13001706 / ISO 9001-QM-0090-13001706 / ISO 10002-CM-0090-13001706)

(Marka Patent No / Trademark)

$(2015 / 04018-2015 / G E / 17595)$

General information regarding gender, age, educational status and occupation for the users of all gated communities, where the questionnaire was carried out, is given below. Out of total participants, $55 \%$ of respondents are women and $45 \%$ are men, which shows that the majority of the respondents are women. Survey results show that, $1 \%$ of the respondents are below the age of $18,5 \%$ are between 19-25, 25\% are between 26-35, 35\% are between $36-45,21 \%$ are between $46-$ $55,11 \%$ are between $56-65$, and $2 \%$ of the respondents are above the age of $66.61 \%$ of respondents report to have bachelor's degree; $34 \%$ have high school education and 5\% have only secondary school education or lower. The results reveal that there is diversity in terms of education among the users who participated in the questionnaire. Regarding occupational distribution of the users, $46 \%$ are employed, $31 \%$ are housewives, $19 \%$ are retired and $4 \%$ are students.
The second part of the survey includes the perception of the users who were questioned to understand their satisfaction with 3 main factors, which are houses, housing estates and the neighborhood. In addition to the literature analysis, the housing qualities of the gated communities, the possibilities offered by them and different locations in the neighborhood were taken into account when preparing the questions of the survey. Data related to the apartments were examined in 6 topics, whereas data related to the housing estates were examined in 7 , and data related to the neighborhood were examined in 8 topics. Based on the scores from the survey out of one hundred, first the satisfaction level of the users was evaluated (Table 2). Negative aspects regarding dissatisfaction were marked with bold characters. Then, under the same headings, the answers given by the users were evaluated and the importance given to apartments, housing estates and neighborhood preferences were scored (Table 3). 


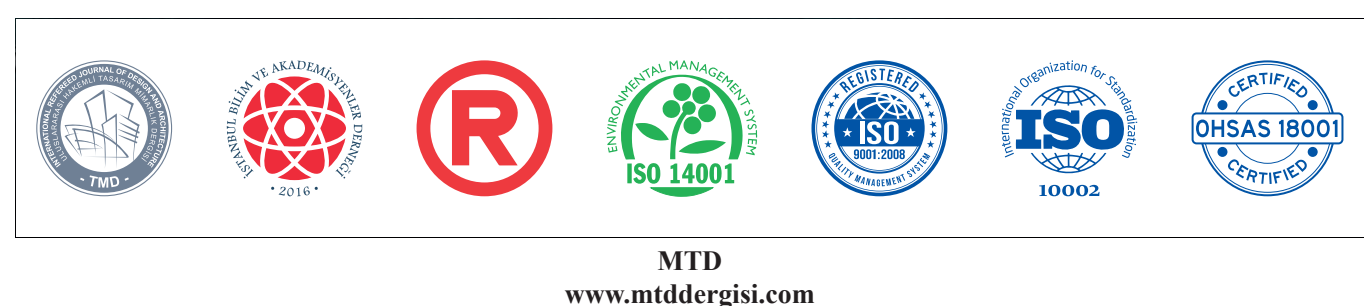

www.mtddergisi.com

ULUSLARARASI HAKEMLİ TASARIM VE MIMARLIK DERGISİ

Mayıs / Haziran / Temmuz / Ăgustos Yıl: 2018 Sayı: 14 İlkbahar Yaz Dönemi

INTERNATIONAL REFEREED JOURNAL OF ARCHITECTURE AND DESIGN

May / June / July / August Year: 2018 Issue: 14 Spring Summer

ID:295 K:340

ISSN Print: 2148-8142 Online: $2148-4880$

(ISO 18001-OH-0090-13001706 / ISO 14001-EM-0090-13001706 / ISO 9001-QM-0090-13001706 / ISO 10002-CM-0090-13001706)

(Marka Patent No / Trademark)

$(2015 / 04018-2015 / G E / 17595)$

\section{Table 2. Status of User Satisfaction}

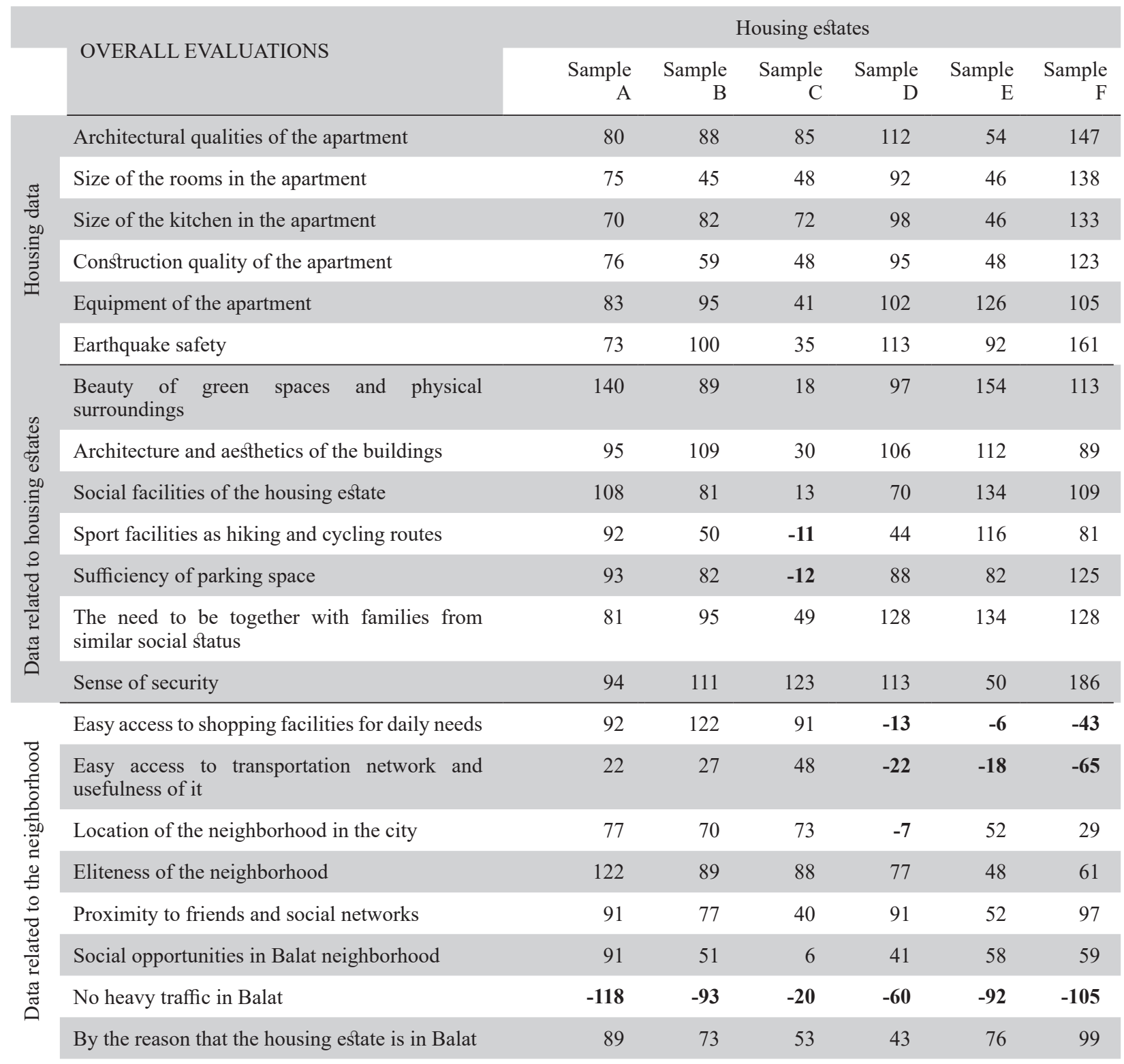




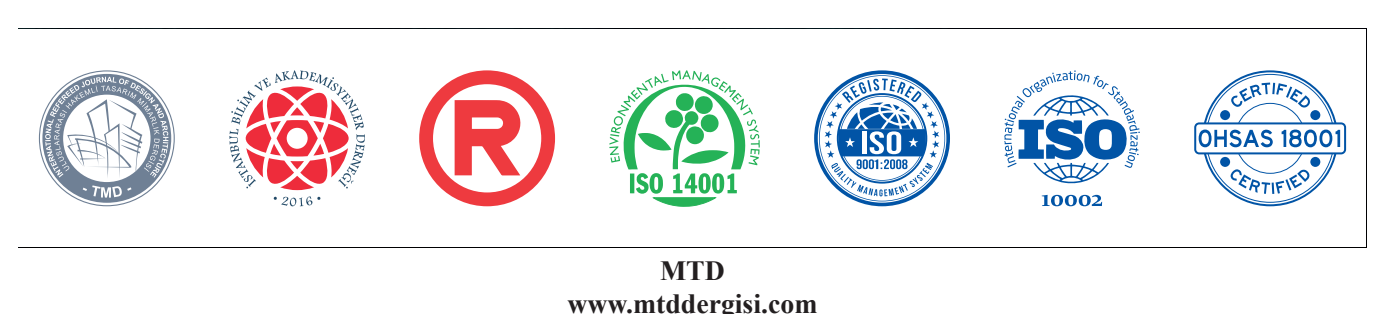

www.mtddergisi.com

ULUSLARARASI HAKEMLİ TASARIM VE MIMARLIK DERGISİ

Mayıs / Haziran / Temmuz / Ağustos Yıl: 2018 Sayı: 14 İlkbahar Yaz Dönemi

INTERNATIONAL REFEREED JOURNAL OF ARCHITECTURE AND DESIGN

May / June / July / August Year: 2018 Issue: 14 Spring Summer

ID:295 K:340

ISSN Print: 2148-8142 Online: 2148-4880

(ISO 18001-OH-0090-13001706 / ISO 14001-EM-0090-13001706 / ISO 9001-QM-0090-13001706 / ISO 10002-CM-0090-13001706)

(Marka Patent No / Trademark)

$(2015 / 04018-2015 /$ GE/17595)

Table 3. Status of Importance Level and Order of Importance of Residents (I.L.: importance level, O.I: order of importance)

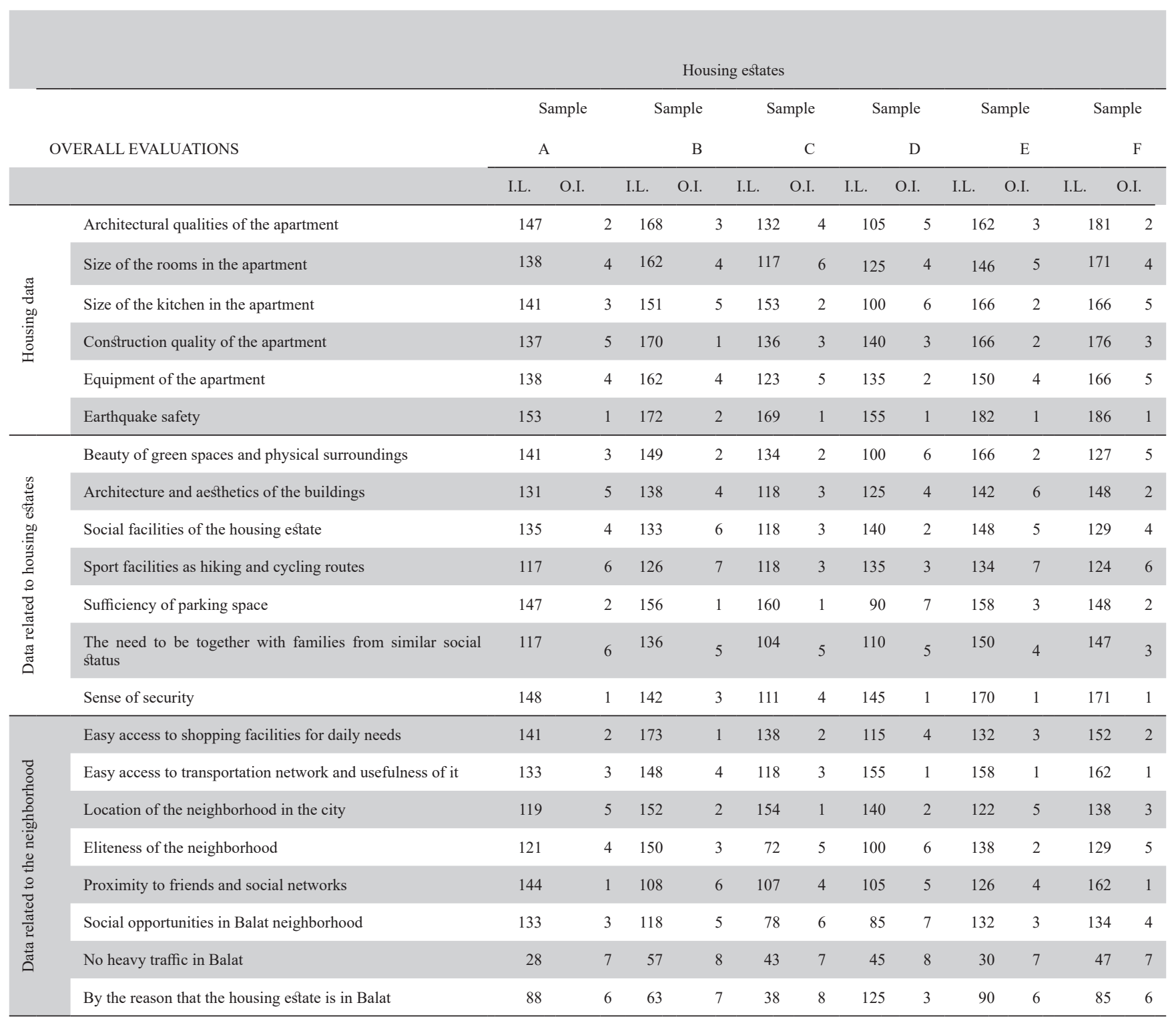

The findings of user satisfaction based on the data related to housing, housing estate and neighbourhood in Balat are discussed comparing with the findings in literature in the next part. 


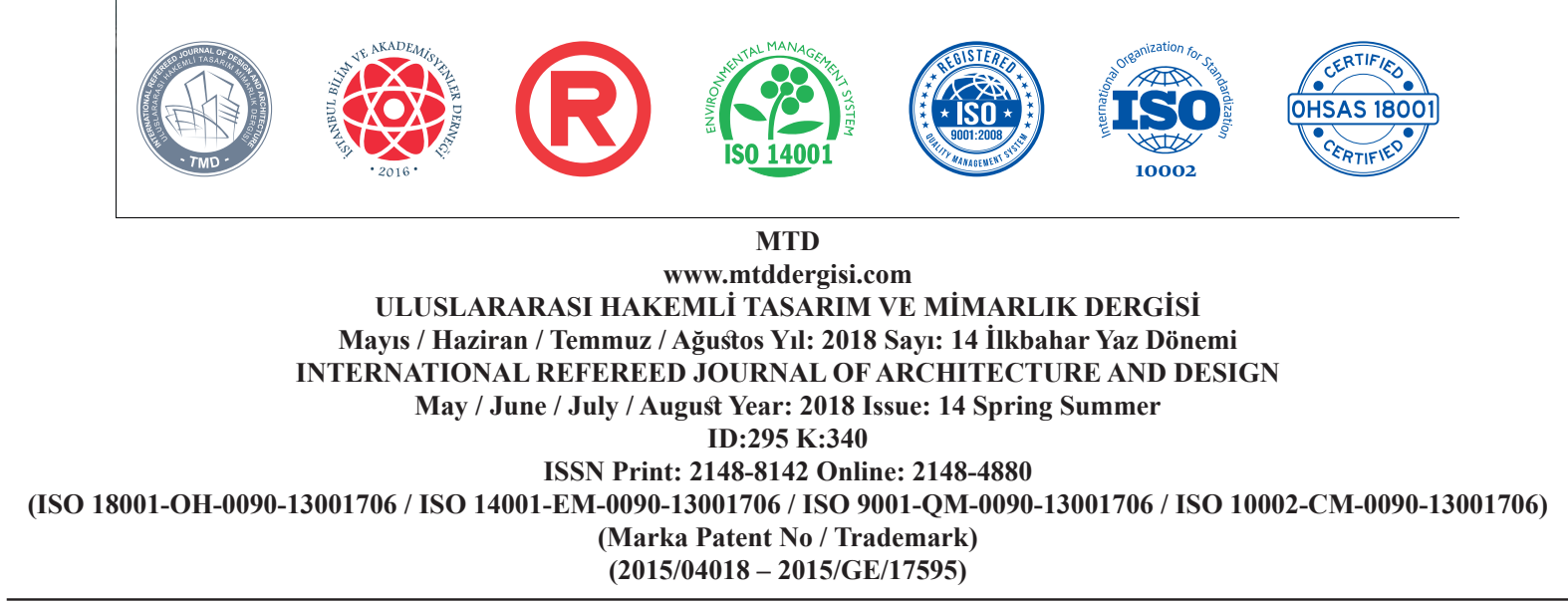

\section{DISCUSSION}

The results obtained in Table 2 and Table 3 were evaluated about user preferences and satisfaction under 3 main topics:

- HOUSING DATA: The housing data were examined under the headings of architectural qualities of the apartment, size of the rooms, size of the kitchen, construction quality of the building, equipment of the house and earthquake safety.

Satisfaction analysis: It has been seen that residents are generally satisfied with earthquake safety, architectural qualities of the apartment, features, but are moderately satisfied with the size of rooms and kitchens and construction quality.

Significance Analysis: In all sites, earthquake safety was the most important factor of satisfaction. Construction and architectural qualities of the building are often secondary factors, and the size of the kitchen was given more significance in some areas and less in others. The degree of significance of other topics varies between houses.

\section{- DATA RELATED TO HOUSING}

ESTATES: This was evaluated with topics of green spaces and physical surroundings, architecture, aesthetics, social facilities, hiking and cycling routes etc. sports facilities, sufficiency of parking space, the need to be together with families from similar social status, and sense of security.

Satisfaction Analysis: Among the data of the housing sites, the topics that provided the highest level of satisfaction were the sense of safety provided by the security of the site, a life spent with families that have similar social status, and the aesthetic appearance of the site architecture, while satisfaction with the social facilities of the housing estate was high, medium and low. When the parking adequacy of the sites is evaluated, it is observed that there is a medium or high level satisfaction in general, and satisfaction with walking, cycling routes and sports facilities are usually moderate. In the case of $\mathrm{C}$, it has been observed that satisfaction level of both the parking capacity and the bicycle roads and other sports opportunities was moderate, and also it was seen that satisfaction level of all users from all aspects was lower than other housing estates.

Significance Analysis: When the data from the gated communities are examined, it is observed that the most important reason for the preference is the safety of the site in general and the importance of feeling safe in the residential area. Parking capacity, green spaces and physical environment had secondary significance. Some of the moderately important criteria such as social facilities and aesthetics of the site architecture 


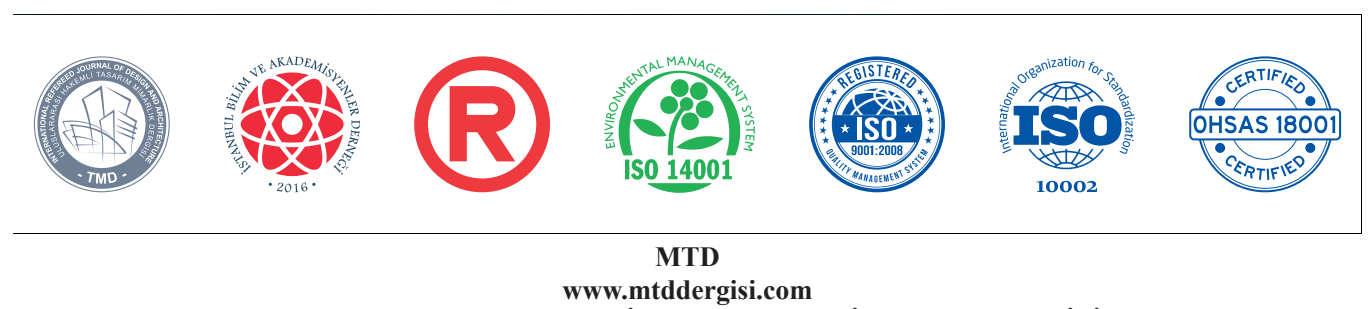

ULUSLARARASI HAKEMLİ TASARIM VE MIMARLIK DERGISİ

Mayıs / Haziran / Temmuz / Ağustos Yıl: 2018 Sayı: 14 İlkbahar Yaz Dönemi

INTERNATIONAL REFEREED JOURNAL OF ARCHITECTURE AND DESIGN

May / June / July / August Year: 2018 Issue: 14 Spring Summer

ID:295 K:340

ISSN Print: 2148-8142 Online: 2148-4880

(ISO 18001-OH-0090-13001706 / ISO 14001-EM-0090-13001706 / ISO 9001-QM-0090-13001706 / ISO 10002-CM-0090-13001706)

(Marka Patent No / Trademark)

$(2015 / 04018-2015 / G E / 17595)$

varied between housing estates. It is concluded that sports facilities such as walking and bicycle roads, and living together with similar families in terms of social status were less important preferences than others.

\section{- DATA RELATED TO THE}

NEIGHBORHOOD: Accessibility of shopping facilities for daily needs, proximity to transportation network and usefulness of the network, accessibility, location of the neighborhood in the city, eliteness of the neighborhood, proximity to friends and social networks, social opportunities in the neighborhood, status of the traffic and the reason to live in the neighborhood originating from the location of the housing estate were examined under the popularity and location topics.

Satisfaction Analysis: When the data related to the neighborhood is analyzed, it is noteworthy that the satisfaction level of the residents on this topic is generally lower than the satisfaction levels of the other two main topics. Satisfaction levels of being in an elite community and the housing estates being in Balat neighborhood are the highest in the dimensions regarding the desire to be close to friends and the social networks, which were expressed as moderate or high. Satisfaction with other topics is low or moderate. The level of satisfaction with regard to ease of access to daily shopping is high in areas A, B and C, which are close to shopping areas, while low in areas D, E and F, which are slightly further away from shopping areas. Similarly, the level of satisfaction with accessibility and usability of the transportation network is medium in sites of $\mathrm{A}, \mathrm{B}$ and $\mathrm{C}$ and low in sites of $\mathrm{D}, \mathrm{E}$, and $\mathrm{F}$. The lowest satisfaction is with traffic in Balat neighborhood, and this discomfort can be seen significantly in all housing estates.

Significance Analysis: Although there was no preference that was significantly more important than other preferences related to the neighborhood, it was often stated that the most important factor was easy accessibility to the transportation network, transportation network's suitability, ease of access to shopping areas for daily needs and the good location in the city. In some housing estates, desire to be close to friends and social networks, and in some housing estates Balat's eliteness were attached secondary significance. Having many social opportunities in the neighborhood was of medium importance, and the importance given to other factors varied among housing estates.

When all the data is evaluated in general, the relationship between user satisfaction and significance has been brought into light.

In Figure 14, the satisfaction / significance matrix is given as the evaluation criteria for housing. 


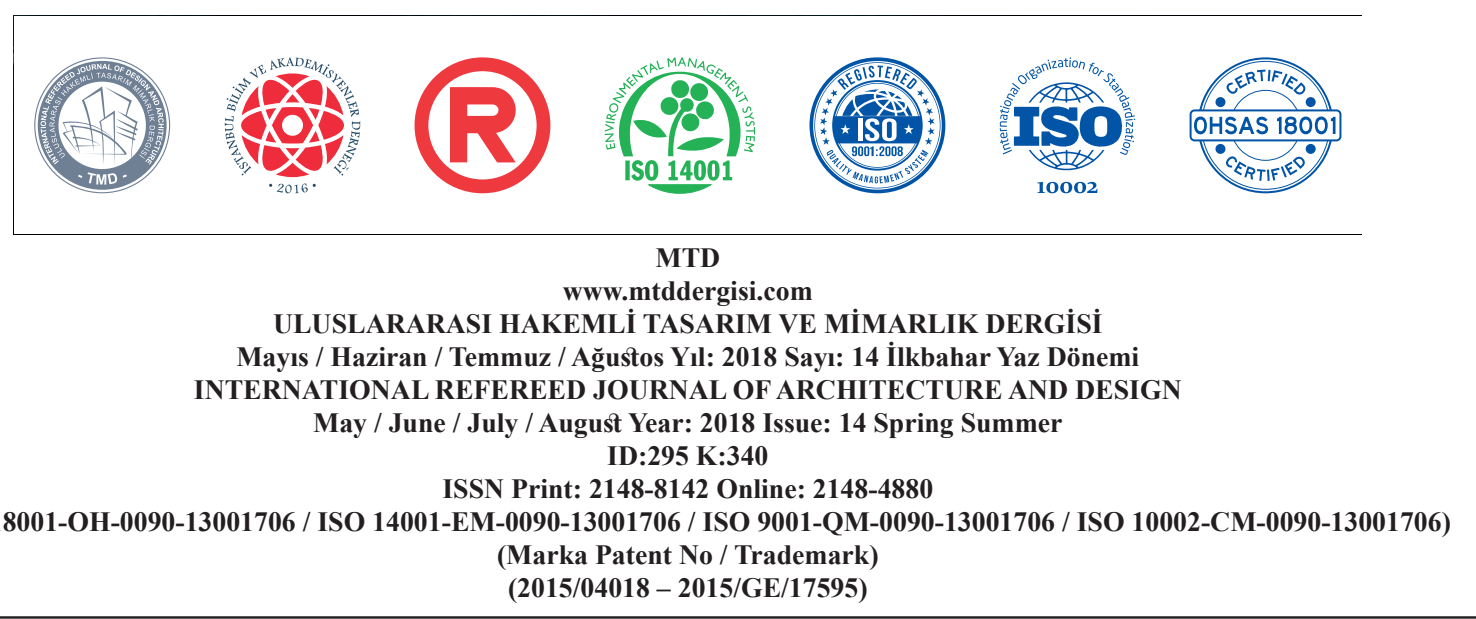

(ISO 18001-OH-0090-13001706 / ISO 14001-EM-0090-13001706 / ISO 9001-QM-0090-13001706 / ISO 10002-CM-0090-13001706)

$(2015 / 04018-2015 / G E / 17595)$

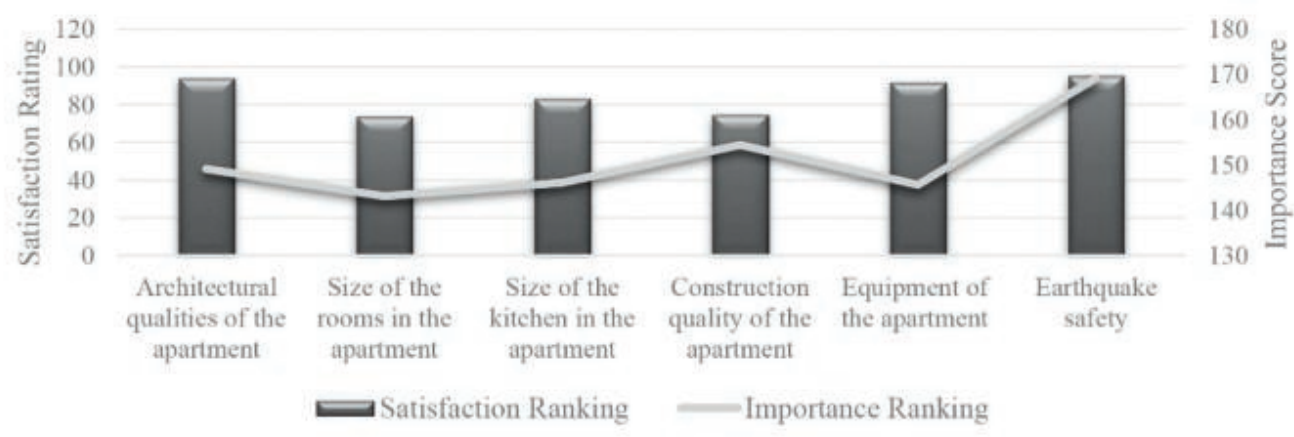

Figure 14. Satisfaction / Importance Matrix of the Criteria Related to Evaluation of Houses and Discussion

A high satisfaction level was observed in housing estates, where users give the highest significance to earthquake safety. The second reason for preference was the construction quality and architectural qualities, and it was seen that satisfaction with the construction quality is lower than other factors. However, the level of satisfaction with architectural qualities is very high. It is also seen in different studies in the literature that the physical qualities of the apartments have influence on satisfaction (Türkoğlu 1997, Li and Song 2009, Salleh 2008). It is noteworthy that despite being an unimportant factor for the preference of users, satisfaction with houses that are well-equipped was high. A similar situation is also true for the size of kitchens; despite the fact that kitchen size wasn't given high importance; the proportion of users who are satisfied with the size of the kitchen was high. In the survey, where the size of the rooms was of less important for users' preferences, it is observed that the satisfaction of the users with room sizes was lower than the other factors. Figure 15 shows the satisfaction / importance matrix related to the evaluation criteria of the housing estates. 


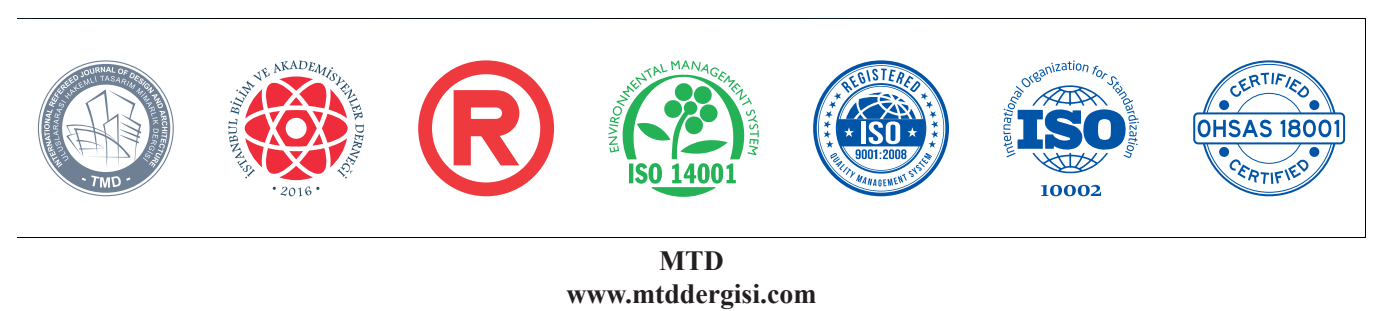

www.mtddergisi.com

ULUSLARARASI HAKEMLİ TASARIM VE MIMARLIK DERGISİ

Mayıs / Haziran / Temmuz / Ağustos Yıl: 2018 Sayı: 14 İlkbahar Yaz Dönemi

INTERNATIONAL REFEREED JOURNAL OF ARCHITECTURE AND DESIGN

May / June / July / August Year: 2018 Issue: 14 Spring Summer

ID:295 K:340

ISSN Print: 2148-8142 Online: 2148-4880

(ISO 18001-OH-0090-13001706 / ISO 14001-EM-0090-13001706 / ISO 9001-QM-0090-13001706 / ISO 10002-CM-0090-13001706)

(Marka Patent No / Trademark)

$(2015 / 04018-2015 / G E / 17595)$

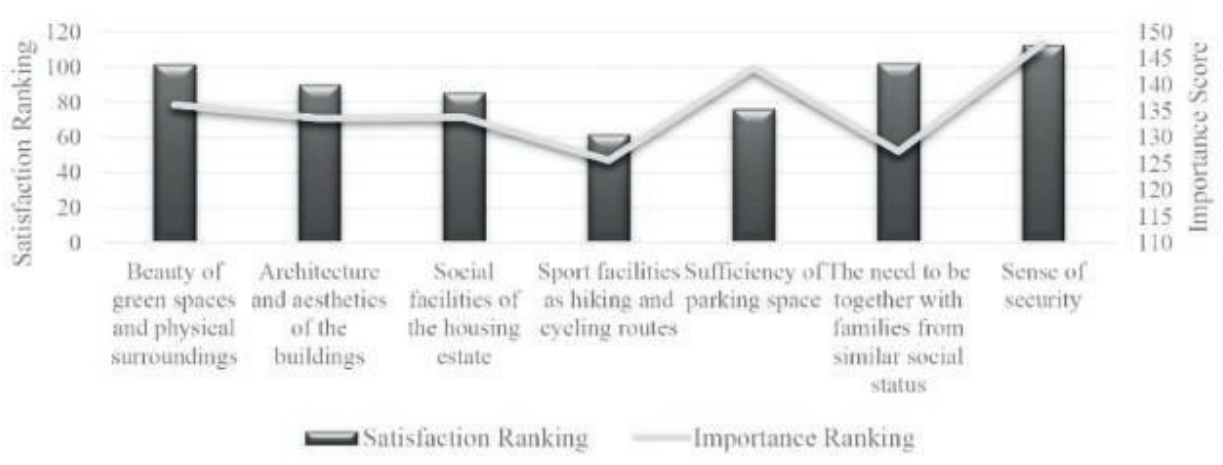

Figure 15. Satisfaction / Importance Matrix of the Criteria Related to Evaluation of Housing Estates and Discussion

It was seen that for users, the most important reason for selecting gated communities in the Balat neighborhood was safety and the feeling of safety and the satisfaction level of this factor was high. The sense of safety is also a major factor in the literature, affecting user preferences and satisfaction in gated communities in relation to the raising children in a safe place (Carvalho et al., 1997, Lee et al., 2007, Chapman, Lombard, 2006). Satisfaction with parking capacity, which is a secondary important factor for user preferences, does not meet the level of importance given by the users, and it has been seen that the satisfaction of the users in terms of parking capacity is generally in the low-medium level. One notable point is that although it was not an important factor for user preference, users are very satisfied with living together with families in similar social status. The preference of earthquake safety in terms of the physical aspects of the gated communities in Balat, social safety, social status and a privileged life in terms of the social aspects are in line with studies conducted in İstanbul (Özkan Töre and Kozaman Som, 2009). It is observed that the level of satisfaction of the quality of housing estates' green spaces and social facilities, aesthetic level of the physical environment and the architecture, and the other qualities related to sports facilities is in line with the importance given by users.

In Figure 16, the satisfaction / significance matrix is given as the evaluation criteria of the neighborhood. 

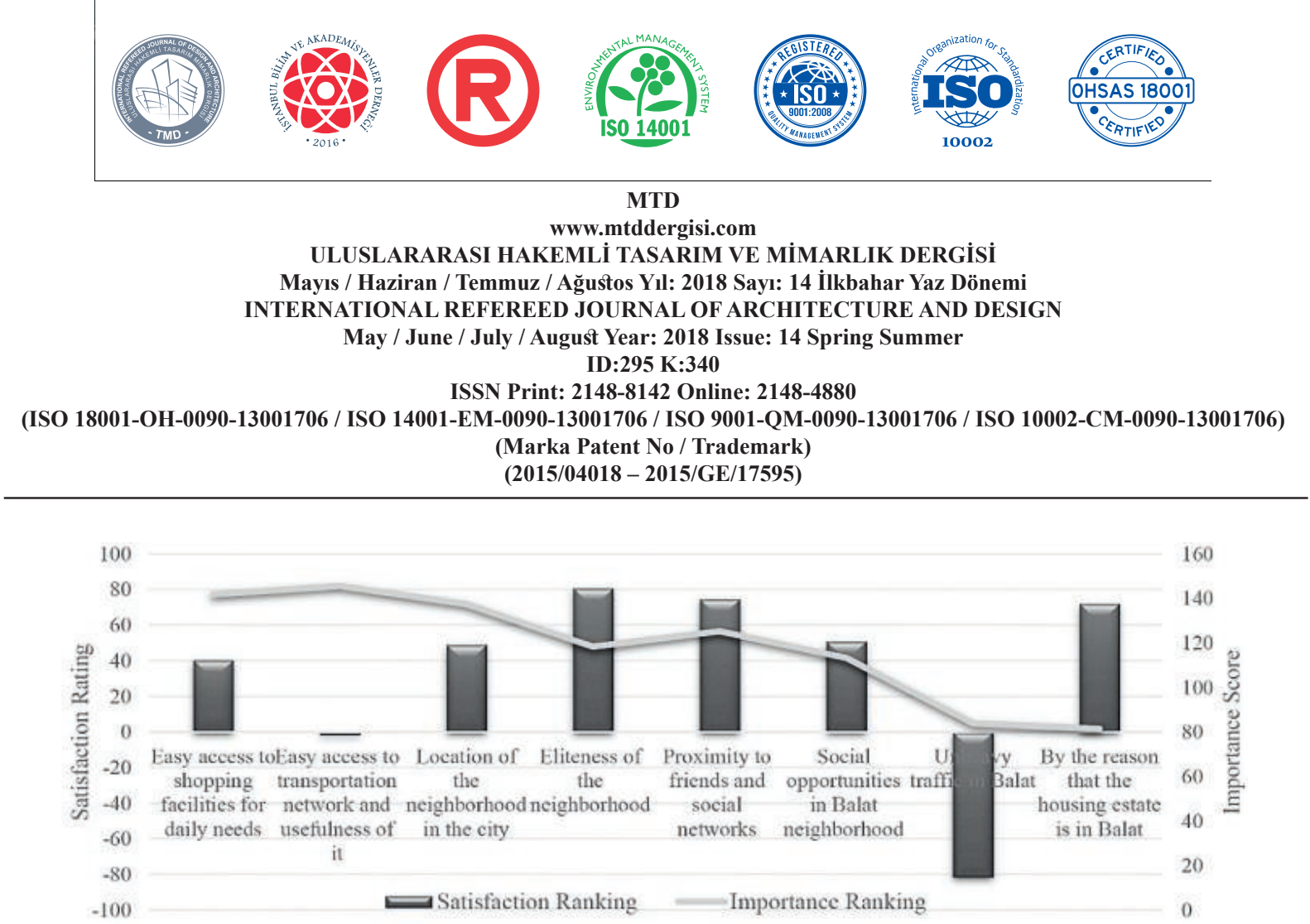

Figure 16. Satisfaction / Importance Matrix of the Criteria Related to Evaluation of the Neighborhood and Discussion

It is interesting to see the low level of satisfaction with factors that played an important role for preferring Balat and the highly satisfactory factors, which users did not give significance while preferring Balat. It is seen that even though the ease of access to the transportation network and the network's suitability were the most important factors for preferring Balat, the level of satisfaction with these factors is very low. The availability of public transport facilities and its impact on satisfaction with the neighborhood are in line with other studies (Jun, 2013, Berköz et al. 2009). Level of satisfaction with easy access to shopping facilities for daily needs, which is among other factors, important for user preference, is low or medium. It is noteworthy that despite being a primary factor, satisfaction with the neighborhood being in a good location in the city was at a moderate level, and satisfaction with traffic was at a low level. Not having a busy traffic became an unimportant factor for selecting the neighborhood and it was seen that users were quite uncomfortable with the traffic in Balat. With regard to the social environment, it is not important that the housing estate is located in Balat, although it is of moderate importance to be in an elite neighborhood during the initial preference. However, it was seen that being in an elite neighborhood and being located in Balat, increase the satisfaction level very much. This is consistent with the subjective reasons of selecting gated communities, which can be summarized as the desire for a better lifestyle, social homogeneity, status and privilege (Roitman, 2005). The desire to be close to friends and social networks had a medium importance but turned out to be satisfying to the user. The broadness of the social opportunities in the neighborhood has not been an important factor for user 


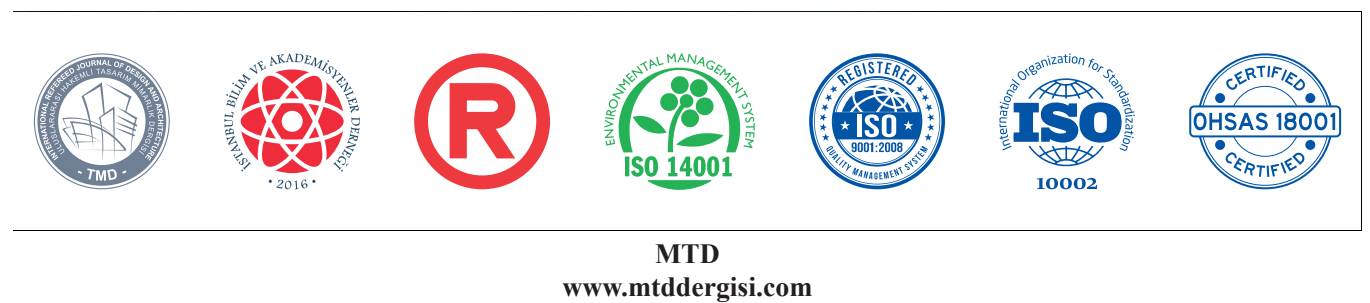

ULUSLARARASI HAKEMLİ TASARIM VE MIMARLIK DERGISİ

Mayıs / Haziran / Temmuz / Ăgustos Yıl: 2018 Sayı: 14 İlkbahar Yaz Dönemi

INTERNATIONAL REFEREED JOURNAL OF ARCHITECTURE AND DESIGN

May / June / July / August Year: 2018 Issue: 14 Spring Summer

ID:295 K:340

ISSN Print: 2148-8142 Online: 2148-4880

(ISO 18001-OH-0090-13001706 / ISO 14001-EM-0090-13001706 / ISO 9001-QM-0090-13001706 / ISO 10002-CM-0090-13001706)

(Marka Patent No / Trademark)

$(2015 / 04018-2015 / G E / 17595)$

preferences, and in parallel, satisfaction has been found to be at sub-moderate levels.

\section{CONCLUSIONS}

Balat neighborhood in the city of Bursa, which has become popular after 2000s and increased in popularity after 2010, which triggered the increase in housing demand and supply, was examined for the criteria that users found significant for preferring this district, and the lifestyles provided by the buildings sites with the satisfaction levels of users with these criteria in this study. By investigating user preferences for gated communities and the level of satisfaction with their preferences, fruitful results were obtained, which may have an impact on building supply and explain reasons for choosing certain locations. The evaluation on housing qualities, and the qualifications related to the housing estate and the neighborhood, along with the user characteristics, have provided results that explain the causality of the increasing popularity of the neighborhood despite the factors which are not satisfactory to the users.

When the housing qualities are considered in Balat firstly, it is seen that earthquake safety is the most important factor affecting user preferences, and in housing estates where the satisfaction level of earthquake safety is high, various factors, which were not initially important such as architectural qualities of the house, how well equipped the house is, and the kitchen size, play an important role on satisfaction. When the lifestyle offered by the housing estates is evaluated, it is seen that the most important factor for users that prefer these sites are the sense of security, in other words the feeling of safety at the housing estate, of which users are highly satisfied. Despite the importance given by users, the general unsatisfactory level of parking spaces indicates that the parking spaces are inadequate for the user vehicles. In such housing estates, parking space is reserved for 1 or 2 vehicles in general, and insufficient space is reserved for guest vehicles, which are among the reasons for inadequateness. The aesthetic value of the housing estates is also important, but social facilities, green spaces, sports facilities or physical qualities are of less importance both in the sense of significance and satisfaction. It has been observed that the importance given by the users in the housing estates on criteria related to accessibility and transportation was not in line with the levels of satisfaction. In this scope, besides the differences regarding the housing estates, even though day to day shopping needs and ease of access to the transportation network were important factors for user preference, satisfaction levels were not good in general. The most important factor in Balat's preference is the ease of access to the transportation network and the convenience of the network, of which 


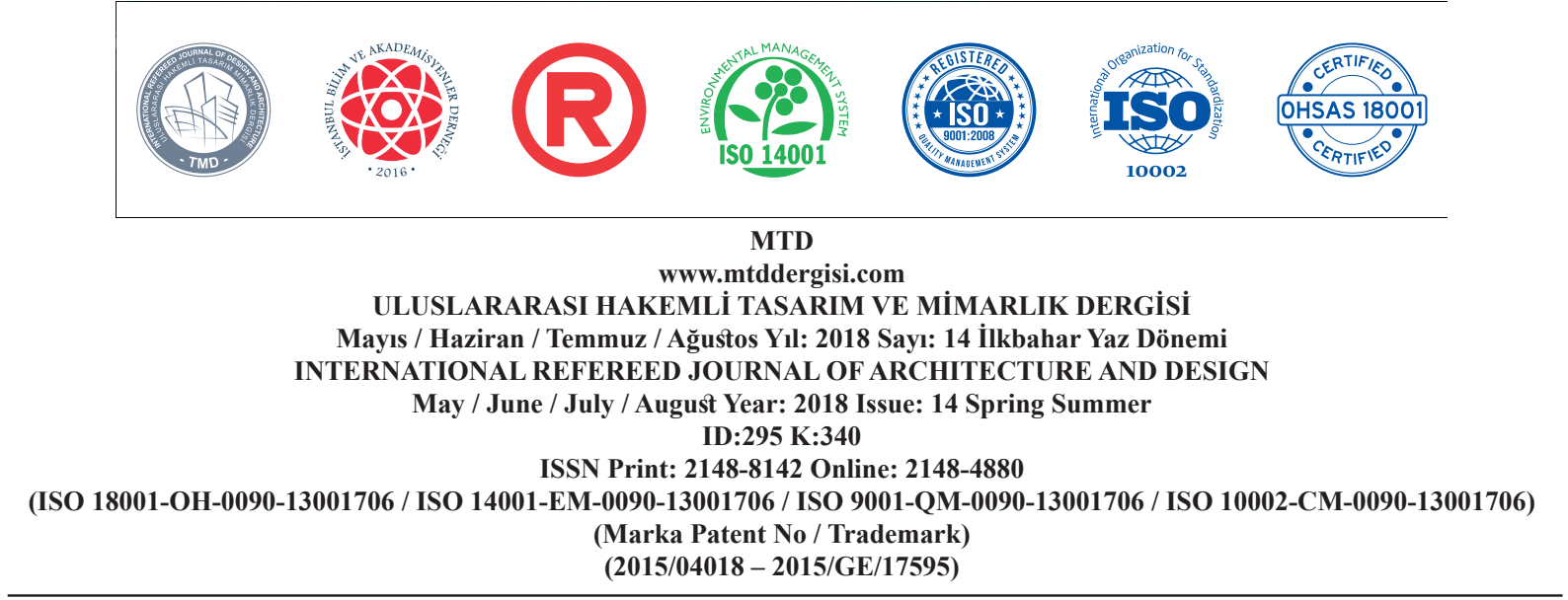

user satisfaction was very low throughout the neighborhood. Despite the importance given, users were not satisfied with the location of the district within the city. It is observed that the facilities for daily shopping needs, ease of access to the transportation network and the satisfaction with the usefulness of the transportation network differ clearly between housing estates. Low satisfaction levels at D, $\mathrm{E}$ and $\mathrm{F}$ sites and high satisfaction levels in the other sites are related to the different locations. The main intersections at which two main roads connect have many commercial buildings, including the commercial facilities of the $\mathrm{C}$ site, and can be considered to be the center of the neighborhood. When considered to be the center, the samples A, B and C are located on three sides of this intersection / center, whereas D, E and F are located farther away from the center. In this case users living at $\mathrm{A}, \mathrm{B}$ and $\mathrm{C}$ sites can access shopping facilities, various commercial facilities and the transportation network on foot, and although it is only public busses, they can reach alternative public transportation options. Balat's topography has many slopes, which makes it impossible for users living in D, E and F sites to reach shopping facilities or commercial facilities on foot, therefore users can only go shopping with their private vehicles; also the transportation network is only fed by one bus line therefore it is impossible to go anywhere on foot. In addition to these, although not reaching negative values like in $\mathrm{D}, \mathrm{E}$ and $\mathrm{F}$ sites, access to the transportation network at all sites is difficult and the network is regarded useless. The reason for this is although the neighborhood is very busy it does not have any other public transport opportunity except for one bus line that reaches the neighborhood once every hour and another one that only goes to the neighborhood center at certain hours. This situation negatively affects the satisfaction of the users, who do not have a private car and the servants who work in the houses. It is seen that the uncomfortable traffic in Balat is a problem in the neighborhood because the whole area is reached via only one junction connecting two main roads from different parts of the city, creating high traffic especially in the morning and evening and is unable to accommodate the number of vehicles.

Even though there are negativities affecting everyday life in Balat, the reasons explaining the increasing popularity of the housing estates and the neighborhood are clear from the results obtained in the study. A factor associated with housing estates is that although it is not very significant initially, users feel very satisfied from living with families that are of similar social status. It can be stated that the similar structure of the families supports the sense of security. This shows that users that prefer Balat's gated communities 


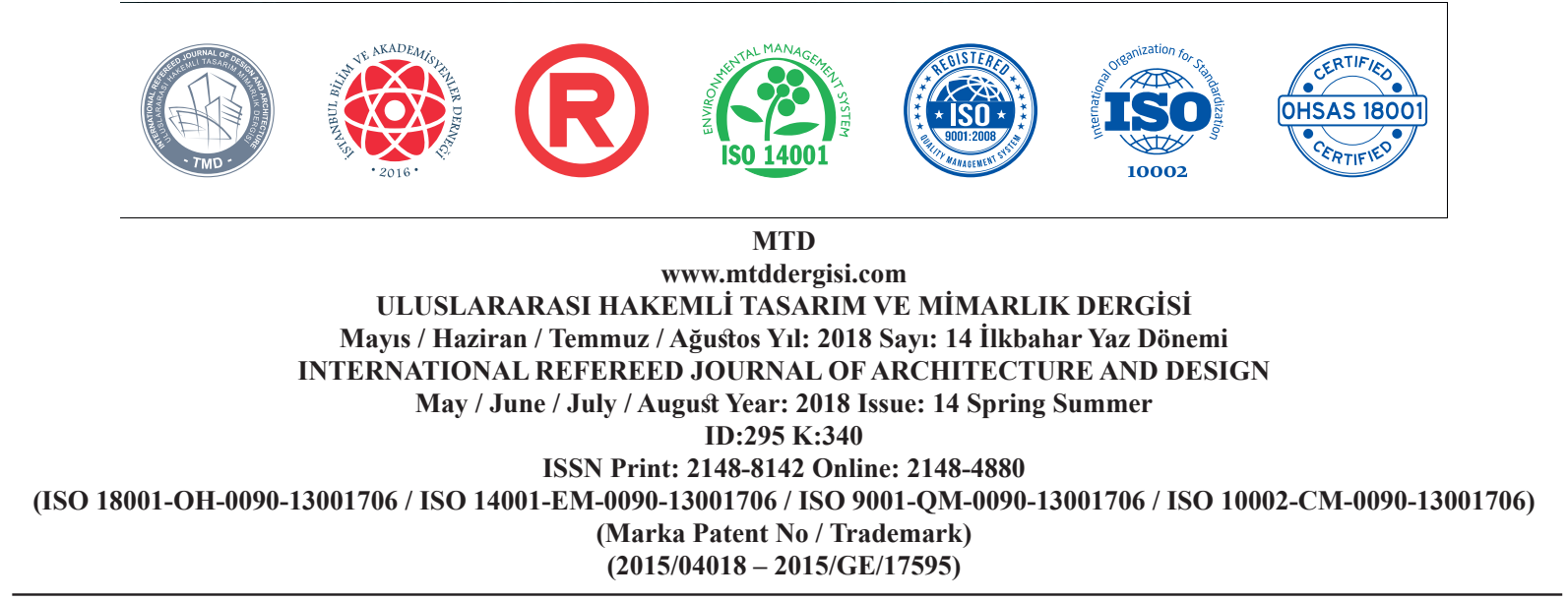

are satisfied with their privileged life, and that they believe that they have a better lifestyle together with other families that reached a "certain status", which increases their satisfaction.

Despite the low levels of satisfaction with factors that played an important role in preferring Balat, some factors that were not important initially increased the satisfaction of the users after moving to these housing estates. It was observed that although the elite status of the neighborhood and the location of the housing estates being in Balat were not important in the beginning, they became factors that satisfied users very much. This situation is in interaction and in line with the high satisfaction of the users with living together with families that have similar social status. Although it has medium importance during the initial preference of the housing estates, being close to friends and social networks increased the satisfaction of users even though the social facilities of the neighborhood were found to be inadequate. This shows that users living in Balat are very satisfied with their social status and belonging to an "elite" group.

When the findings are compared with other studies and regions at the national and international scale, in the evaluation made at the national scale, it is seen that security, privileged life and earthquake safety are crucial in gated communities in Turkey. The factors affecting preferences and satisfaction at $\mathrm{Ba}$ lat are consistent with the situation in Turkey. When it is examined in Istanbul city which is the biggest city of the country, it is seen that, differently from Balat, provision of services and technology are more developed and users attach importance to this point in most of the gated communities. On an international scale, recreational qualities in the United States, social facilities in Brasil seem to be more effective different from Balat. In Egypt and China, the transportation factor becomes prominent similarly to Balat. The prominence of safety in USA and Brasil, and prominence of social environment and segregation in USA, Argentina, Brasil, Egypt and India are similar to Balat in that social environment is related to safety and lifestyle. The results show that social environment is more prevalent than the house and housing estate qualities in preference of Balat and those social and physical factors are effective on satisfaction.

\section{RECOMMENDATIONS}

The differences in the level of wealth in Bursa are an important factor affecting spatial dissolution similar to other cities today. Balat, where the upper income group is concentrated, is the most obvious area in the city, where the effects of purchasing power on preferences can be observed. The results of the research have shown that problems such as transportation difficulties and traffic, and 


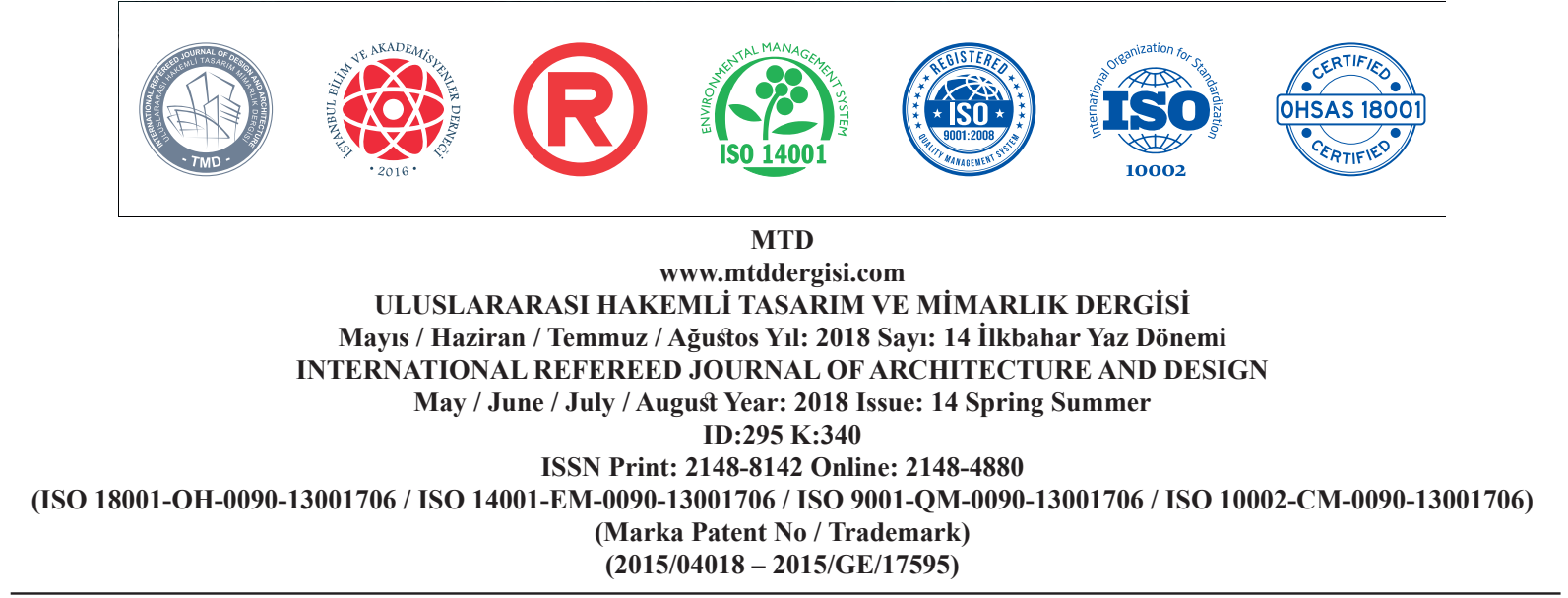

positive/negative physical qualities related to housing estates, which have a negative impact on daily life and create dissatisfaction, remain in the background, and being individuals belonging to a certain social status and living a privileged life together with those individuals in Balat influence user preferences and increase the popularity of the neighborhood.

When an evaluation is made with respect to future of gated communities, the importance on preference and effect on satisfaction of accessibility and transportation factor show that it is necessary to be more careful in site selection for this kind of housing developments.

It can be said that the time factor is also influential on housing preferences and satisfaction. Rapidly evolving technology, changing and accelerating lifestyles, increasing role and importance of technology in people's lives as time passes by increase the requirement of service and technical equipment in gated communities. In the same way, with the globalization and dense migration, the urban population that is increasingly becoming cosmopolitan and the increasing safety need trigger the foreground of safety and social segregation in gated communities. With the development of technology and the growing importance of service procurement, projects should be produced that take into account the changing needs. In this framework, the technological change that the time brings, the equipment and services expected by the individual should be predicted.

In the next step of this study, the positive or negative aspects of gated communities can be discussed. It should be aimed to raise awareness of the users for the purpose of preference of the house and housing area focusing on the needs, expectations and factors that are taken into consideration separately from the "popularity" of the neighborhood. It should also be targeted to provide the actors to focus on user satisfaction that takes part in planning, design and implementation processes.

\section{REFERENCES}

AMERIGO, M., ARAGONES, J.I., (1997).

A theoretical and methodological approach to the study of residential satisfaction, Journal of Environmental Psychology, (17): 47-57, Doi: 10.1006/jevp.1996. 0038

BERKÖZ, L., (2008). İstanbul'da korunakl1 tek-aile konutları: Konut kalitesi ve kullanıcı memnuniyetinin belirlenmesi, İTÜ Dergisi/a, Mimarlık Planlama Tasarım, 7(1): 110-124

BERKÖZ, L., TURK, Ş.Ş., KELLEKCI Ö.L., (2009). Environmental quality and user satisfaction in mass housing areas: The case of Istanbul, European Plan- 


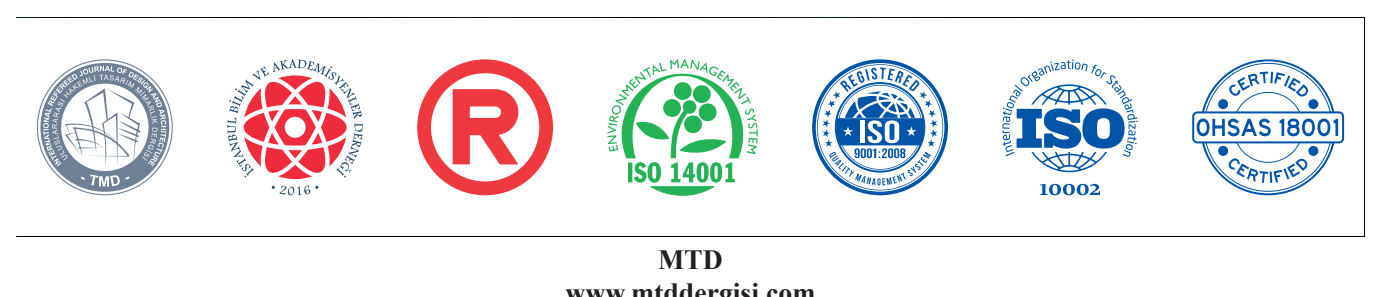

www.mtddergisi.com

ULUSLARARASI HAKEMLI TASARIM VE MIMARLIK DERGİSI

Mayıs / Haziran / Temmuz / Ă̆ustos Yıl: 2018 Sayı: 14 İlkbahar Yaz Dönemi

INTERNATIONAL REFEREED JOURNAL OF ARCHITECTURE AND DESIGN

May / June / July / August Year: 2018 Issue: 14 Spring Summer ID:295 K:340

ISSN Print: 2148-8142 Online: 2148-4880

(ISO 18001-OH-0090-13001706 / ISO 14001-EM-0090-13001706 / ISO 9001-QM-0090-13001706 / ISO 10002-CM-0090-13001706)

(Marka Patent No / Trademark)

$(2015 / 04018-2015 / G E / 17595)$

ning Studies, 17(1): 161-174, Doi: 10.1080/09654310802514086

BLAKELY, E.J., SYNDER, M.G., (1997). Fortress America: Gated communities in the United States, Washington: U.S: Brookings Institution Press

CARVALHO, M., GEORGE R. V., ANTHONY, K.H., (1997). Residential satisfaction in condominios exclusivos (gateguarded neighborhoods) in Brazil, Environment and Behavior, 29(6): 734-768, Doi: 10.1177/0013916597296002

CHAPMAN, D.W., LOMBARD, J.R., (2006). Determinants of neighborhood satisfaction in fee-based gated and nongated communities, Urban Affairs Review, 41(6): 769-799, Doi: $10.1177 / 1078087406287164$

\section{CLAPHAM, D., FOYE, C., CHRISTIAN,}

J., (2017). The concept of subjective well-being in housing research, Housing, Theory and Society 25(3): 261-280

DOSTOĞLU, N.T., (2000). Bursa' da farkl1 konut alanlarinda çevresel anlam, Yap1, 221: $62-70$

\section{FRIJTERS, P., JOHNSTON, D. W.,} SHIELDS, M.A., (2011). Life satisfaction dynamics with quarterly life event data, The Scandinavian Journal of Economics, 113(1): 190-211
HA M., WEBER M.J., (1991). The determinants of residential environmental qualities and satisfaction: Effects of financing, housing programs and housing regulations, Housing and Society, 18(3): 65-76, Doi: 10.1080/08882746.1991.11430119

IBRAHIM, M.R., (2017). How do people select their residential locations in Egypt? The case of Alexandria, Cities, 62(2017): 96-106, Doi: 10.1016/j.cities.2016.12.012

LEE, H.J., GOSS, R.C., BEAMISH, J.O., (2007). Influence of lifestyle on housing preferences of multifamily housing residents, Housing and Society, 34(1): 11-30, Doi: $10.1080 / 08882746.2007 .11430542$

LI, S., SONG, Y., (2009). Redevelopment, displacement, housing conditions and residential satisfaction: A study of Shanghai, Environment and Planning A, 41(5): 1090-1108

JUN, M.J., (2013). The effects of housing preference for an apartment on residential location choice in Seoul: A random bidding land use simulation approach, Land Use Policy 35(2013): 395-405, Doi: 10.1016/j.landusepol.2013.06.011

MUTLU, E., VAROL, Ç., (2017). Sosyo-ekonomik farklılaşma ve mekânsal ayrışma:Bursa Metropoliten Alanı 


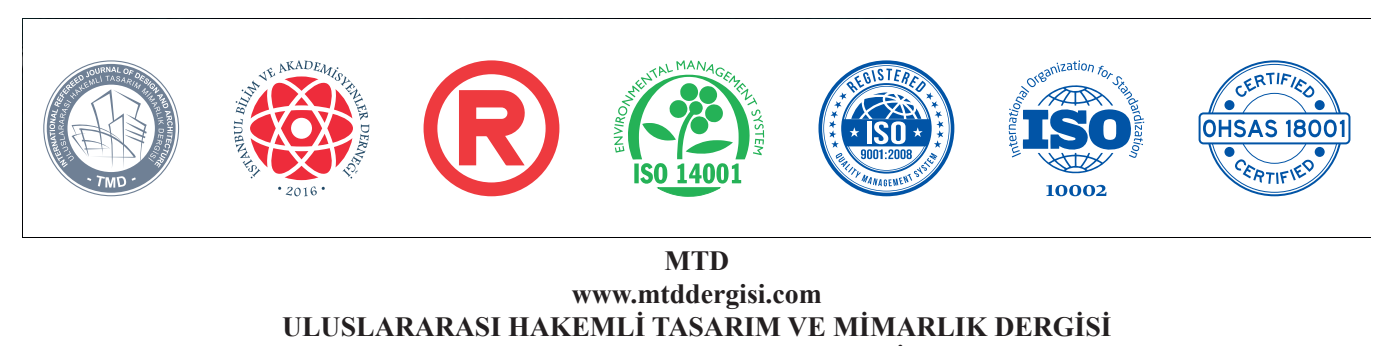

ULUSLARARASI HAKEMLİ TASARIM VE MIMARLIK DERGİSI

Mayıs / Haziran / Temmuz / Ağustos Yıl: 2018 Sayı: 14 İlkbahar Yaz Dönemi

INTERNATIONAL REFEREED JOURNAL OF ARCHITECTURE AND DESIGN

May / June / July / August Year: 2018 Issue: 14 Spring Summer ID:295 K:340

ISSN Print: 2148-8142 Online: $2148-4880$

(ISO 18001-OH-0090-13001706 / ISO 14001-EM-0090-13001706 / ISO 9001-QM-0090-13001706 / ISO 10002-CM-0090-13001706)

(Marka Patent No / Trademark)

$(2015 / 04018-2015 / G E / 17595)$

analizi, Megaron, 12(1): 87-105, Doi: 10.5505/megaron.2016.04695

ÖZKAN, TÖRE, E., KOZAMAN, SOM, S., (2009). Sosyo-mekansal ayrışmada korunaklı konut yerleşmeleri: İstanbul örneği, Megaron 4 (3): 121-130

QIAO, S., HAN, N., ZHOU, J., LI, R.H., JIN, C., GUTIERREZ, L.A., (2018). SocialMix: A familiarity-based and preference-aware location suggestion approach, Engineering Applications of Artificial Intelligence 68: 192-204, Doi: 10.1016/j.engappai.2017.11.006

ROITMAN, S., (2005). Who segregates whom? The analysis of a gated community in Mendoza, Argentina, Housing Studies, 20(2): 303-321, Doi:10.1080/026730303 042000331790

SALLEH, A.G., (2008). Neighbourhood factors in private low-cost housing in Malaysia, Habitat International, 32(4): $\quad 485-493, \quad$ Doi: $10.1016 / j$. habitatint.2008.01.002

SAM, N., BAYRAM, N., BILGEL, N., (2012). The perception of residential environment quality and neighbourhood attachment in a metropolitan city: A study on Bursa, Turkey, eCanadian Journal of Humanities and Social Sciences, 1(1): 22-39

SIRGY, M,J., CORNWELL, T., (2002). How neighborhood features affect quality of life, Social Indicators Research, 59(1): 79-114, Doi: 10.1023/A:1016021108513

TECK-HONG, T., (2012). Housing satisfaction in medium- and high-cost housing: The case of Greater Kuala Lumpur, Malaysia, Habitat International 36(1): 108-116, Doi: 10.1016/j.habitatint. 2011.06 .003

TRAN, T,Q., VAN VU, H., (2018). А microeconometric analysis of housing and life satisfaction among the Vietnamese elderly, Quality\&Quantity, 52(2): 849-867

TÜRKO $\breve{G L U, ~ H . D ., ~(1997) . ~ R e s i d e n t s ' ~}$ satisfaction of housing environments: the case of Istanbul, Turkey, Landscape and Urban Planning, 39(1): 55-67

WILSON-DOENGES, G., (2000). An exploration of sense of community and fear of crime in gated communities, Environment and Behavior, 32(5): 597-611

WOLBRING, T., (2017). Home Sweet Home! Does Moving Have (Lasting) Effects on Housing Satisfaction?, Journal of Happiness Studies, 18(5): 1359-1375

YÜKSEL, U., AKBULUT, M.T., (2009). Tüketim Odaklı Mimarlığın Son Y1llardaki Yeni Ürünleri: Rezidanslar, Megaron, 4(2): 110-118 